\title{
Spatial Scale-Depended Characteristic Of Moss and Soil C, N, P and K Stoichiometry and Their Relationships In A Temperate Desert of Central Asia
}

Yonggang Li ( $\sim$ liyg@ms.xjb.ac.cn )

State Key Laboratory of Desert and Oasis Ecology https://orcid.org/0000-0002-5166-7804

Xiao-Bing Zhou

State Key Laboratory of Desert and Oasis Ecology

Yongxing Lu

State Key Laboratory of Desert and Oasis Ecology

Yuanming Zhang

State Key Laboratory of Desert and Oasis Ecology

\section{Research Article}

Keywords: Ecological stoichiometry, Moss, Soil nutrients, Spatial scale, Climate factors

Posted Date: April 16th, 2021

DOI: https://doi.org/10.21203/rs.3.rs-375598/v1

License: (c) (i) This work is licensed under a Creative Commons Attribution 4.0 International License.

Read Full License 


\section{Abstract}

Background and aims: Previous studies showed that moss stoichiometric characteristics were influenced by moss patch size and shrubs in desert. Study of moss stoichiometry in different spatial scales is crucial for understanding of growth and adaptation strategy of the mosses in temperate desert.

Methods: In this study, the dominant moss (Syntrichia caninervis Mitt.) of biological soil crusts, and soil under the moss patches in the Gurbantunggut Desert were selected to determine their stoichiometry in different dunes and sites. Carbon $(C)$, nitrogen $(N)$, phosphorus $(P)$ and potassium $(K)$ contents of the moss and soil, and soil available nutrients were measured.

Results: Moss stoichiometry and soil available nutrients were significantly influenced by changes in spatial distance scales except for moss $\mathrm{C}$. The scaling exponents of moss $\mathrm{N}, \mathrm{P}$ and $\mathrm{K}$ elements between above-ground and below-ground parts were $0.251,0.389,0.442$, which were less than 1 . The N vs. P scaling exponents were $0.71,0.84$ in above-ground and below-ground parts of moss. Moss $\mathrm{C}, \mathrm{P}$ and $\mathrm{K}$ elements content in above-ground parts higher than that in below-ground parts. Moreover, moss N, P and $\mathrm{K}$ elements were influenced by MAP, longitude and soil nutrients.

Conclusion: This study provided the $\mathrm{C}, \mathrm{N}, \mathrm{P}$ and $\mathrm{K}$ stoichiometric characteristics of desert moss and explored their relationships with environmental variables, which can help understand nutrient stoichiometry patterns and utilization strategy of $\mathrm{N}, \mathrm{P}$ and $\mathrm{K}$ and their potential responses to global climate changes in the desert ecosystem of central Asia.

\section{Introduction}

Mosses, as an important components of biological soil crusts, are common components of boreal, arctic, temperate and dryland ecosystems worldwide (Belnap, 2006; Elbert et al., 2012; Lindo and Gonzalez, 2010). Mosses play key functional roles in the ecosystems where they are prevalent (Belnap, 2006; Bowker et al., 2011; Maestre et al., 2012). In drylands, biocrusts mosses support a range of ecosystem functions, including soil stability, carbon (C) and nitrogen $(\mathrm{N})$ fixation, $\mathrm{CO}_{2}$ flux, and $\mathrm{N}$ mineralization (Bowker et al., 2011; Eldridge and Greene., 1994; Maestre et al., 2012; Su et al., 2012; Su et al., 2013; Wu et al., 2015). Drylands are extremely important for achieving global sustainability, as they constitute $41 \%$ of Earth's land surface (Pravalie, 2016; Reynolds et al., 2007). Drylands are also estimated to expand by the end of this century as a result of expected increases in aridity with climate change (Dai, 2013; Feng and Fu, 2013; Huang et al., 2016). More and more researchers have focused on the functions of moss, including C and N cycling (Bowker et al., 2013; Hu et al., 2014; Li et al., 2019a), surface energy balance (Couradeau et al., 2016; Rodriguez-Caballero et al., 2015; Rutherford et al., 2017), erosion (Canton et al., 2014; Chamizo et al., 2017; Zhao and Xu, 2013; Knapen et al., 2007) and water redistribution (Bowker et al., 2013; Kidron et al., 2012; Kidron and Vonshak, 2012; Kidron and Tal, 2012; Kidron and Budel, 2014). Biocrust microbial activity produces extracellular organic exudates that alter the immediate environment by supporting a stable structure and altering the water retention and transport properties of the biocrusts 
(Rodriguez-Caballero et al., 2015). The resulting modification of local hydrological processes, such as infiltration run-off and water storage (Chamizo et al., 2012, 2017). Ecological functions of moss are important for ecosystem process. Growth characteristic of the mosses is essential for their successful survival, which are related to the understanding of moss functions.

In drylands, several methods were used for determination of moss growth characteristic, including molecular (Gao et al., 2015; Yang et al., 2015; Zhang et al., 2018), cytobiology (Oliver et al., 2000a; Oliver et al., 2000b), morphology (Pan et al., 2016b; Tao and zhang, 2012) and physiology (Yin and Zhang, 2016; Yin et al., 2017; Zhang and Zhang, 2014). Moss studies focused on individual and small scale of the mosses. However, mosses are patchily and wildly distributed in desert ecosystem (Bowker et al., 2014; Bowker et al., 2013; Zhang et al., 2007). Ecological stoichiometry, which approaches ecological questions by asking how the balance of elements required by organisms affects processes and interactions, is a valid method to study moss growth characteristic in different spatial scales. However, the ecological stoichiometry was rarely used in moss studies (Ball and Guevara, 2015; Ball and Virginia, 2014). Previous studies have found that moss stoichiometry is easily influenced by environments (Ball and Guevara, 2015; Li et al., 2019a; Li et al., 2019b), and that moss growth showed consistent Potassium (K) or N-K colimitation in peatleads (Wang et al., 2016). Potassium is an important nutrient element which can enhance plant $\mathrm{N}$ retention (Chiwa et al., 2019; Osaki, 1995) and influence the plant growth and photosynthetic rate in vascular plant (Cuzzuol et al., 2013). Carbon, $\mathrm{N}$ and $\mathrm{P}$ are essential components of all organisms and soil. Carbon (C) is the basis of plant growth, reproduction and structure, and constructs about $50 \%$ of plant dry weight (Liu et al., 2011). Nitrogen (N) is the major component of all enzymes and chlorophyll in plants which plays an important role in controlling carbon uptake and primary production (Chen et al., 2016). Phosphorus (P) is a key element in plant ribosome production and responsible for the construction of RNA, DNA and ATP, playing an important role in genetic information transmission, energy storage and cell construction (Bai et al., 2012; Chen et al., 2013). Potassium as a signal substance can improve nitrogen absorption and photosynthetic capacity of plants. Moreover, potassium can also improve the resistance of plants in arid areas and buffer the effect of water deficiency (Damon and Rengel, 2007; Samar Raza et al., 2013). The content of plant nitrogen, phosphorus, potassium plays a key role in plant growth, photosynthesis and environmental adaptability (Elser, 2000; Gusewell, 2004; Hedin, 2004; Samar Raza et al., 2013). Most ecosystem processes are constrained by nutrient cycling between plants and soil, adaptation of plants and soil to environment, and plant ecological functions (Aerts and Chapin, 2000; Bowker et al., 2013; Chapin, 1980; Moody et al., 2018). Plant stoichiometry characteristics play an essential role for understanding plant growth characteristics and ecological functions in different spatial scales.

The C:N:P stoichiometry in above- and below-ground components of ecosystems are tightly connected and their interactions greatly affect ecosystem components, structure and functions (Zeng et al., 2016; Zeng et al., 2017; Yang et al., 2018; Bai et al., 2019). Specifically, leaf and root nutrient stoichiometry would influence plant growth and ecosystem processes and functions (Yang et al., 2018; Bai et al., 2019). The C:N and C:P rate would indicate the $\mathrm{N}$ and $\mathrm{P}$ use efficiency and plant growth rate (Elser et al., 2003; Zhang et al., 2020). The $N$ : P should change with growth rate, and show plant growing with $\mathrm{N}$ limited or $\mathrm{P}$ 
limited (Shi et al., 2021; Liu et al., 2021). The N:P ratio and the N vs. P scaling exponent both can indicate nutrient allocation, the relative accumulation rate of $\mathrm{N}$ compared $\mathrm{P}$, especially the latter, which intrinsically reflects the covariation between $\mathrm{N}$ and $\mathrm{P}$, and indicates the life history of plants and the productivity and nutrient cycle of ecosystem (Sardans and Penuelas, 2015; Tian et al., 2019; Guo et al., 2020; Zhao et al., 2020; Zhang et al., 2018). There has a better link between potassium and terrestrial ecosystem functions, and structural variables such as growth and nutrient cycling (Sardan and Penuelas, 2021). Plant nitrogen, phosphorus and potassium content is affected by environmental factors, including mean annual precipitation (MAP), mean annual temperature (MAT) and soil nutrient content (Liu et al., 2019; Han et al. 2005; Yuan et al., 2009;.Sardans and Penuelas, 2015). Plants and soil nutrients are influenced by each other. For example, plants litter and root exudates would provide carbon of substrates for soil organisms, while decomposer organisms in the soil supply nutrients to plants (Bardgett and Wardle, 2003; Lambers et al., 2009; van der Heijden et al., 2008; Wardle and Zackrisson, 2005). These feedback processes take place in the above-ground and below-ground parts of the ecosystem, which inlfuence ecosustem nutrient cycling. In terrestrial ecosystems, primary producer are frequently limited by the soil nutrients, such as soil available N and P (Elser et al., 2010; Gusewell, 2004; Harpole et al., 2011; Venterink, 2011), changes in which can affect plant growth rate and homogeneity (Elser et al., 2007; Falkowski et al., 2000). Under environmental stress, the simultaneous and reasonable distribution of nitrogen and phosphorus in plants is conducive to the stability of metabolism and the maximization of growthSynchronous and reasonable allocation of $\mathrm{N}, \mathrm{P}$ and $\mathrm{K}$ in plants is conducive to maintaining stable metabolism, maximizing growth and environmental resistance (Zhang et al., 2018; Zhao et al., 2020; Sardan and Penuelas, 2021). In addition, with the coupling of $\mathrm{C}, \mathrm{N}$, and $\mathrm{P}$ stoichiometry between plant and soil more an important research focus (Elser et al., 2010), $\mathrm{K}$ content of plant is the second most abundant nutrient after $\mathrm{N}$, and highlights its great involvement and unavoidable contribution to plant functioning (Sardan and Penuelas, 2015, 2021). These studies focus on forests, shrubs and herbs which are vascular plants (Tränkner et al., 2018; Srivastava et al., 2020; Sardans and Penuelsa, 2015, 2021; Zhao et al., 2020; Shi et al., 2021), however, it is unclear that the relationship between stoichiometric characteristics and growth and environmental adaptability of moss with nonvascular plants. .

It is unclear whether moss growth limited by $\mathrm{N}$ or $\mathrm{P}$, especially in desert ecosystem where is $\mathrm{N}$ deficient and plant growth limted by N (Zhang et al., 2016b; Zhou et al., 2018; Zhou et al., 2014). In addition, The results of previous studies suggest that mosses are poikilohydric, non-vascular plants, which mainly absorb water, $\mathrm{N}$ and $\mathrm{P}$ from the air through above-ground parts (Ayres et al., 2006; Pan et al., 2016a; Tao and zhang, 2012). Carbon, $\mathrm{N}$ and $\mathrm{P}$ of moss are different characteristics between the above- and belowground parts of the mosses (Li et al., 2019a). Moreover, recent studies found that the above-ground parts are the major area of life activity, and accumulation of $\mathrm{C}, \mathrm{N}$ and $\mathrm{P}$ in these parts benefits their functional integrity (Lindo and Gonzalez, 2010; Pan et al., 2015; Rong et al., 2015; Zhang et al., 2017; Zhang et al., 2016a; Li et al., 2019a). The principal function of the below-ground components of moss is to anchor the plant to the ground, with few nutrients taking up from the soil (Lindo and Gonzalez, 2010; Li et al., 2019a). There is little research on potassium content of bryophytes in desert ecosystem. Especially, $\mathrm{K}$ is an essential nutrient involved in many important plant physiological processes, and enhance stress 
tolerance (Zhang et al., 2010; Zhao et al., 2014). The stoichiometric characteristic of mosses was a significant plasticity, and higher sensitivity than vascular plants in desert (Ball and Guevara, 2015; Zhang et al., 2016). Thus, documenting C, N, P and K content of mosses and their stoichiometric characteristic influenced by spatial distribution are important for the understanding of their environmental adaptability mechanism and growth in different habitats of desert ecosystems.

Moss crusts are widely distributed in the Gurbantunggut Desert, Central Asia (Zhang et al., 2007). Moss crust are continuous in the bottom of the sand dunes, while are not in the top. We found that the stoichiometric characteristics of the moss are influenced by microhabitats and moss patch size, which means that nutrient content of moss show obvious and significant changes with the changes of spatial scales. It is unclear that weather stoichiometry characteristics of the moss is remarkably different in different spatial distance $(<1 \mathrm{~km},>10 \mathrm{~km})$ scales. Our objectives in this study are to 1$)$ explore the stoichiometric characteristics of the mosses in different spatial distance scales; 2) determine the relationships of stoichiometric characteristics between above and below-ground parts of moss, and their relationships with environmental variables. Two following hypothesis were tested: (1) the stoichiometric characteristics of the moss would vary significantly with bottoms of three continuous typical sand dunes ( $<1 \mathrm{~km}$ scale) and spatial distance distribution scales ( $>10 \mathrm{~km}$ scale), due to the nutrient content of moss show obvious and significant changes with the changes of spatial scales; (2) unlike vascular plants, which absorb water and nutrients from below-ground parts, moss N, P and K contents in aboveground parts of the mosses would not be influenced by soil nutrients, directly influenced by climate factors in temperature deserts.

\section{Materials And Methods}

\subsection{Site description}

The study was conducted in the Gurbantunggut Desert $\left(44^{\circ} 11^{\prime}-46^{\circ} 20^{\prime} \mathrm{N}, 84^{\circ} 31^{\prime}-90^{\circ} 00^{\prime} \mathrm{E}, 300-600 \mathrm{~m}\right.$ a.s.I.), which is located in the center of the Jungger Basin, Central Asia (Li et al., 2019a). It is the largest fixed and semi-fixed desert, and the second largest desert in China, with the area of $4.88 \times 10^{4} \mathrm{~km}^{2}$. Moist air currents from the Indian Ocean are blocked by the Himalayas and fail to reach this area, resulting in a vast expanse of arid terrain. Annual precipitation ranges from 70 to $260 \mathrm{~mm}$, most of which occurs from April to July, while potential mean annual evaporation is estimated at $2606.6 \mathrm{~mm}$. The mean annual temperature is $7.26^{\circ} \mathrm{C}$ (Zhang et al., 2007). The moss $S$. caninervis is widely distributed in the Gurbantunggut Desert. Plant in the surrounding of the mosses are dominantly Ephedra distachya, Calligonum leucocladum, Seriphidium terraealbae, Artemisia arenaria, Erodium oxyrrhynchum, Carex physodes. The samples were collected with two different spatial distance scales ( $<1 \mathrm{~km}$ and $>10 \mathrm{~km})$. In scale $>10 \mathrm{~km}$, moss and soil samples were obtained from 44 sites in the Gurbantunggut Desert in August 2017 (Fig. 1). The distance between each other is about $10 \mathrm{~km}$. There was no significantly different in particle size of sample sites. The soil particle size $<1 \mathrm{~mm}$ accounted for $96 \pm 2 \%$ in per site. Moss abundance and cover differed across the sites.

\subsection{Sample collection and processing}


There have five plots of $10 \mathrm{~m} \times 10 \mathrm{~m}$ in each site. The samples of moss and soil were selected randomly in the plot. Five discrete moss patches were sampled at each site $(n=5$ per site). Moss-dominated crusts tend to be found in expose area as a sampling point where the distance was farther than $30 \mathrm{~cm}$ to shrubs. Although moss frequently co-occurs with cyanobacteria in cryptobiotic crusts, we selected moss patches occurring without a visible lichen or cyanobacterial component. In scale $<1 \mathrm{~km}$, moss and soil were sampled from continuous bottom of three typical sand dunes for studying of the moss and soil characteristic in different sand dunes $(n=5 \times 3=15)$. All of samples were collected from the flat interdunes where edaphic properties were homogeneous.

At each sampling site, the moss crusts (about $2 \mathrm{~cm}$ thickness) were first carefully collected from the soil and the moss shoot samples were stored in a plastic bag (Quintarabio, China; http://www.quintarabio.cn) in cooling boxes. Next, a cutting ring ( $5 \mathrm{~cm}$ high, $5 \mathrm{~cm}$ diameter) was used to collect soil samples under the moss patches from where the moss crusts had been collected (Li et al., 2019a,b). The samples of moss crust were taken to the laboratory where the above- and below-ground parts of the moss were separated and cleaned carefully with water. Specially, the moss samples were washed sequentially with water on sieves of decreasing pore size $(2,1$, and $0.5 \mathrm{~mm}$ ) and sand was excluded (Li et al 2019a). The parts of moss above-ground and below-ground were oven-dried at $65^{\circ} \mathrm{C}$ for 48 hours. Soil samples were air dried before analysis.

The $\mathrm{C}, \mathrm{N}$, and $\mathrm{P}$ contents of the above- and below-ground parts of $\mathrm{S}$. caninervis were determined. We determined the $\mathrm{C}$ content with a total organic carbon analyzer by using a solid dry combustion method (Han et al. 2005). Total $\mathrm{N}(\mathrm{mg} / \mathrm{g}$ ) was measured using an elemental analyzer (2400 II CHN Elemental Analyzer; Perkin-Elmer, USA). Total P (mg/g) was determined by molybdenum-antimony antispectrophotometric method (Han et al., 2005). Total K content was measured with an atomic absorption spectrophotometer (Perkin Elmer model 2380, Perkin Elmer Inc., USA).

Soil nutrient levels, namely organic $\mathrm{C}(\mathrm{OC})$ total $\mathrm{N}(\mathrm{TN})$, total P (TP), total $\mathrm{K}(\mathrm{TK}), \mathrm{NO}_{3}+\mathrm{NO}_{2}-\mathrm{N}\left(\mathrm{NO}_{3}-\mathrm{N}\right)$, $\mathrm{NH}_{4}-\mathrm{N}$, available $\mathrm{P}(\mathrm{AP})$ and available $\mathrm{K}(\mathrm{AK})$ were determined. Soil OC contents were determined by the dichromate oxidation method. Soil TN and TP contents were measured using the Kjeldahl procedure after digestion with concentrated $\mathrm{H}_{2} \mathrm{SO}_{4}$ on a distillation unit, and the $\mathrm{HClO}_{4}-\mathrm{H}_{2} \mathrm{SO}_{4}$ ammonium molybdateascorbic acid method, respectively. Total $\mathrm{K}$ were measured by inductively-coupled plasma spectrometry (Perkin Elmer Optima 3000-DV ICP, Perkin Elmer Inc., Shelton, Connecticut, USA). For extractable inorganic $\mathrm{N}\left(\mathrm{NO}_{3}+\mathrm{NO}_{2}-\mathrm{N}\right.$ and $\left.\mathrm{NH}_{4}-\mathrm{N}\right), 20 \mathrm{~g}$ soil was extracted in $50 \mathrm{ml} 2 \mathrm{M} \mathrm{KCl}$, filtered, and then frozen until run on a Lachat autoanalyzer (Barrett et al., 2007). Molybdenum-antimony colorimetric method was used to analyze the AP content (Bao, 2000). For the AK, $5 \mathrm{~g}$ soil was extracted in $50 \mathrm{ml} 1 \mathrm{~mol} / \mathrm{LNH}_{4} \mathrm{Ac}$, filtered, and then frozen until run on an atomic absorption spectrophotometer (Perkin Elmer model 2380, Perkin Elmer Inc., USA).

The mean annual precipitation (MAP) and mean annual temperature (MAT) were collected in website: http://www.resdc.cn.

\subsection{Statistics}


The scaling relationship of multiple nutrients among the plant organs is described by the following equations:

\section{$\mathrm{Y}=\beta \mathrm{X}^{\alpha}$}

or $\log (Y)=\log (\beta)+\alpha \log (X)$

where $\mathrm{X}$ and $\mathrm{Y}$ are the elemental concentrations of moss. The reduced major axis (RMA) was applied to estimate the parameters of $a$ and $b$ in the scaling function. When $a=1$, the relationship of $X$ to $Y$ is probably isometric; otherwise, the scaling relationship is considered allometric. When a $>1$, it is assumed that $Y$ changes faster than linearly with $X$, whereas $a<1$ indicates that $X$ changes faster than linearly with respect to $Y$.

Moss $\mathrm{C}, \mathrm{N}, \mathrm{P}$ and $\mathrm{K}$ contents and soil nutrients in different scales of sand dunes and in different sample sites were analyzed using one-way analysis of variance (ANOVA). T-test was conducted on the comparison of moss $\mathrm{C}, \mathrm{N}, \mathrm{P}$ and $\mathrm{K}$ contents, moss $\mathrm{C}: \mathrm{N}, \mathrm{C}: \mathrm{P}, \mathrm{C}: \mathrm{K}, \mathrm{N}: \mathrm{P}, \mathrm{N}: \mathrm{K}$, and $\mathrm{P}: \mathrm{K}$ between above- and below-ground parts. Pearson correlation analysis was used to analyze the correlations between moss stoichiometry in aboveground and belowground, and between moss stoichiometry and soil nutrients. All statistical analyses were performed using R 3.5.0 software (R Development Core Team 2017).

Structural equation modeling (SEM) was developed between the stoichiometric characteristics. The following variables were included in models: the $\mathrm{C}, \mathrm{N}, \mathrm{P}$ and $\mathrm{K}$ content in above-ground parts of moss was used in saturated model which tests the relationship of $\mathrm{C}, \mathrm{N}, \mathrm{P}$ and $\mathrm{K}$ elements; MAP, MAT, latitude, longitude, N, P and K content in soil and above- and below-ground parts of moss were each split into three groups. The model gives path parameters, which can explain the influence of different parameters on moss nutrients. The advantage of this approach was that we could determine which parameters (for example, sign or magnitude of path coefficients) differed among groups, and obtained a separate parameter estimate for each group. The model was considered to be a good fit if the data included an insignificant $(P>0.05)$ chi-square test statistic, RMSEA $<0.05, P>0.05$, and both GFI and CFI $>0.90$. The SEM analyses were performed using R 3.5.0 software (R Development Core Team 2017).

\section{Result}

\subsection{Moss stoichiometry and soil nutrients in different spatial scale}

$\mathrm{N}$ and $\mathrm{P}$ contents in both above-ground and below-ground parts of moss differed significantly $(P=0.040$, $P=0.002)$ among different sand dunes. No significant differences in moss $\mathrm{C}$ and $\mathrm{K}$ contents of aboveground parts $(P=0.698, P=0.357)$ were found among different sand dunes. However, for the belowground, moss $\mathrm{K}$ content varied significantly $(P=0.037)$ among different sand dunes. Significant differences in $\mathrm{C}: \mathrm{N}, \mathrm{N}: \mathrm{K}$ and $\mathrm{P}: \mathrm{K}$ in above-ground and below-ground parts of moss were found among 
sand dunes. The ratios of $\mathrm{N}: \mathrm{P}$ and $\mathrm{C}: \mathrm{K}$ were not significantly different (above-ground: $P=0.461, P=0.481$; below-ground: $P=0.231, P=0.052$ ) different among continuous interdunes (Table 1). Moss stoichiometry and stoichiometric ratios in aboveg-round parts were significantly affected by different sampled sites, except for moss $\mathrm{C}$ and $\mathrm{P}$ contents and moss $\mathrm{C}: \mathrm{N}$ and $\mathrm{C}: \mathrm{P}$. In below-ground parts, moss $\mathrm{P}$ content and C:N ratio did not differ significantly among sampled sites (Table 1). Moss $\mathrm{N}$ and $\mathrm{P}$ contents in above-ground parts of moss increased with annual mean precipitation increased ( $P=0.02$; Fig. 2a, 2b). Moss $\mathrm{P}$ content in above-ground and below-ground parts of moss was also significantly influenced by annual mean temperature (Fig. 2c). Moss $\mathrm{N}$ content did not significantly change with AMT.

Table 1

One way ANOVA of moss stoichiometry in different dunes and sampling sites. $P$ values were main effects from ANOVA.

\begin{tabular}{|c|c|c|c|c|c|c|c|c|c|c|}
\hline Moss & C & $\mathbf{N}$ & $P$ & $\mathrm{~K}$ & C:N & C:P & C:K & $N: P$ & $\mathrm{~N}: \mathrm{K}$ & $P: K$ \\
\hline \multicolumn{11}{|l|}{$\begin{array}{l}\text { Above- } \\
\text { ground }\end{array}$} \\
\hline $\begin{array}{l}\text { Different } \\
\text { dunes }\end{array}$ & 0.698 & 0.040 & 0.002 & 0.357 & 0.014 & 0.010 & 0.481 & 0.461 & 0.022 & $\dot{0.001}$ \\
\hline $\begin{array}{l}\text { Different } \\
\text { sites }\end{array}$ & 0.825 & 0.004 & 0.630 & $<.001$ & 0.103 & 0.277 & 0.002 & 0.007 & $<.001$ & 0.001 \\
\hline \multicolumn{11}{|l|}{$\begin{array}{l}\text { Below- } \\
\text { ground }\end{array}$} \\
\hline $\begin{array}{l}\text { Different } \\
\text { dunes }\end{array}$ & 0.060 & $<.001$ & $\begin{array}{l}< \\
0.001\end{array}$ & 0.037 & 0.033 & 0.523 & 0.052 & 0.231 & $<.001$ & $\dot{c}_{0.001}$ \\
\hline $\begin{array}{l}\text { Different } \\
\text { sites }\end{array}$ & $<.001$ & $<.001$ & 0.95 & $<.001$ & 0.144 & 0.001 & $\begin{array}{l}<.001 \\
0.00\end{array}$ & $<.001$ & $<.001$ & 0.012 \\
\hline
\end{tabular}

For the soils under moss crust, soil TK, $\mathrm{NO}_{3}-\mathrm{N}, \mathrm{NH}_{4}-\mathrm{N}$ and AK contents differed significantly $(P=0.019, P$ $<0.001, P=0.009, P=0.042$ ) among sand dunes (Table 2). Significant differences in soil $\mathrm{TK}, \mathrm{NO}_{3}-\mathrm{N}, \mathrm{NH}_{4}^{-}$ $\mathrm{N}, \mathrm{AP}$ and AK contents $(P=0.009, P<0.001, P=0.006, P<0.001, P<0.001)$ were also observed among different sampled sites.

Table 2

One way ANOVA of soil nutrients in different dune and site. P values were main effects from ANOVA.

\begin{tabular}{|lllllllll|}
\hline Soil & OC & TN & TP & TK & $\mathbf{N O}_{3}{ }^{-}-\mathbf{N}$ & $\mathbf{N H}_{4}{ }^{+}-\mathbf{N}$ & AP & AK \\
\hline Different dunes & 0.631 & 0.584 & 0.135 & 0.019 & $<0.001$ & 0.009 & 0.194 & 0.042 \\
\hline Different sites & 0.090 & 0.221 & 0.214 & 0.009 & $<0.001$ & 0.006 & $<0.001$ & $<0.001$ \\
\hline
\end{tabular}

3.2 Relationships of moss stoichiometry characteristics 
Moss $\mathrm{C}, \mathrm{P}$ and $\mathrm{K}$ contents in above-ground parts of moss were significantly $(P=0.019, P<0.001, P<$ 0.001 ) higher than that in below-ground parts of moss (Table 3). No significant $(P=0.877)$ differences were found in moss $\mathrm{N}$ content in above-ground and below-ground parts of moss. The ratios of $\mathrm{C}: \mathrm{N}$ and P:K in above-ground parts of moss were significantly $(P<0.001, P=0.032)$ higher than that in belowground parts of moss. However, the ratios of $\mathrm{C}: \mathrm{P}, \mathrm{N}: \mathrm{P}$ and N:K in below-ground parts of moss were significantly $(P=0.022, P<0.001, P=0.035)$ higher than those in above-ground parts of moss. Moss C:K ratios between above-ground and below-ground parts were not obviously different $(P=0.929$,Table 3$)$.

Table 3

Result from the T-test of stoichiometry and stoichiometry ratios in above-ground and below-ground of the mosses.

\begin{tabular}{|lllll|}
\hline & Above-ground mean value & Below-ground mean value & $\mathbf{t}$ & $\boldsymbol{p}$ \\
\hline $\mathrm{C}$ & 270.531 & 256.738 & 2.348 & 0.019 \\
\hline $\mathrm{N}$ & 15.692 & 15.746 & -0.1553 & 0.877 \\
\hline $\mathrm{P}$ & 1.410 & 1.278 & 4.695 & $<0.001$ \\
\hline $\mathrm{K}$ & 4.684 & 4.492 & 3.483 & $<0.001$ \\
\hline $\mathrm{C}: \mathrm{N}$ & 17.355 & 16.422 & 3.603 & $<0.001$ \\
\hline $\mathrm{C}: \mathrm{P}$ & 193.37 & 203.001 & -2.293 & 0.022 \\
\hline $\mathrm{C}: \mathrm{K}$ & 58.364 & 58.514 & -0.089 & 0.929 \\
\hline $\mathrm{N}: P$ & 11.195 & 12.409 & -5.359 & $<0.001$ \\
\hline $\mathrm{N}: \mathrm{K}$ & 3.375 & 3.582 & -2.120 & 0.035 \\
\hline $\mathrm{P}: \mathrm{K}$ & 0.302 & 0.288 & 2.155 & 0.032 \\
\hline
\end{tabular}

The SEM model explained $42 \%, 28 \%$ and $23 \%$ of variance in moss $\mathrm{C}, \mathrm{N}$ and $\mathrm{P}$ contents in above-ground parts, respectively (Fig. 3). Moss $\mathrm{P}$ content had the strongest direct effect on moss $\mathrm{N}$ content in aboveground parts. Moss $\mathrm{C}$ content in above-ground parts was positively affected by moss $\mathrm{N}$ content in aboveground parts $(0.53, P<0.001)$, while negatively affected by moss $\mathrm{K}$ content in above-ground parts $(-0.39$, $P<0.01)$. Significantly positive effect was found between moss $\mathrm{K}$ and $\mathrm{P}$ content in above-ground parts $(0.48, P<0.01)$. Weak effects were observed between moss $\mathrm{C}$ and $\mathrm{P}$ content, and between moss $\mathrm{N}$ and $\mathrm{K}$ content in above-ground parts.

The $\mathrm{N}$ vs. $\mathrm{P}$ scaling exponents were 0.71 and 0.84 in above-ground and below-ground of moss respectively, which were less than 1 . The likelihood ratio test indicated that the $\mathrm{N}$ vs. P scaling exponent in below-ground of moss was significantly greater than that in above-ground of moss (Fig. 4). The scaling relationships between above-ground and below-ground of nitrogen, phosphorus and potassium was $0.251,0.389,0.442\left(R^{2}=0.13, P<0.01 ; R^{2}=0.26, P<0.01 ; R^{2}=0.27, P<0.01\right)$, respectively (Fig. 5).

\subsection{Relationships of soil nutrients and moss stoichiometry}


Moss $\mathrm{K}$ contents in above and below-ground parts significantly $\left(P=0.03, \mathrm{R}^{2}=0.13 ; P<0.01, \mathrm{R}^{2}=0.16\right)$ increased with soil AK content (Fig. 6a). Moss $P$ contents in above and below-ground parts showed significant $\left(P=0.04, \mathrm{R}^{2}=0.14 ; P=0.03, \mathrm{R}^{2}=0.14\right)$ and positive correlation with soil $\mathrm{NO}_{3}-\mathrm{N}$ content (Fig. 6b).

The SEM model showed that the effects of climate, latitude, longitude and soil nutrients on moss N, P and $\mathrm{K}$ assimilation differed between above- and below- ground parts of the mosses (Fig. 7-9). The fit of the moss and soil $\mathrm{N}$ model was satisfactory $(\mathrm{GFI}=0.971, \mathrm{CFI}=0.996, \mathrm{RMSEA}=0.023$, Chi-square $=$ $11.760, P=0.382$ ). The model explained $20 \%$ and $23 \%$ of the variance in $\mathrm{N}$ content in above-ground and below-ground parts, respectively (Fig. 7). The strongest direct effect of $\mathrm{N}$ content in above-ground parts was affected by $\mathrm{N}$ content in below-ground parts of moss $(0.31)$, which was significantly affected by soil nutrient content (0.19).

The fit of the $\mathrm{P}$ model was satisfactory $(\mathrm{CFI}=0.970, \mathrm{GFI}=0.953$, RMSEA $=0.040$, Chi-square $=19.339, \mathrm{P}=$ 0.055). In the $P$ model, SEM model explained $46 \%$ of the variation in $P$ content in above-ground parts and $46 \%$ of the variation in P content in below-ground parts of moss (Fig. 8). The strongest direct effect was found between $P$ content in above-ground parts and below-ground parts (0.31). Soil nutrient content strongly affected the $\mathrm{P}$ content in below-ground parts (0.59), and the $\mathrm{P}$ content in above-ground parts (0.49). The soil nutrient content was significantly influenced by MAT (0.71).

The fit of the $\mathrm{K}$ model was satisfactory $(\mathrm{CFI}=0.979, \mathrm{GFI}=0.959, \mathrm{RMSEA}=0.034$, Chi-square $=16.366, \mathrm{P}=$ 0.128). The model explained $48 \%$ of the variance in $\mathrm{K}$ content in above-ground parts of mosses and $33 \%$ of the variance in $\mathrm{K}$ content in below-ground parts (Fig. 9). K content in below-ground parts significantly affected moss $\mathrm{K}$ content in above-ground parts $(P<0.001)$. The soil nutrient content had significant and positive effects on moss $K$ content in below-ground parts $(0.67, P<0.01)$. Soil nutrient content was significantly influenced by MAT $(0.74, P<0.01)$. Latitude and longitude had significantly affected moss $\mathrm{K}$ content in above-ground parts $(0.32,0.33 ; P<0.05)$

\section{Discussion}

\subsection{Different responses of mosses and soil characteristics to variable in spatial scale}

In the current study, no significant differences in moss $C$ content were found in different spatial scales, except that moss $\mathrm{C}$ in below-ground parts. In addition, our previous studies found that moss $\mathrm{C}$ did not shift with changes of moss patch size and microhabitats (Li et al., 2019a; Li et al., 2019b). Thus, our previous and current results suggested that moss $C$ was stable in different spatial scales from patch size $(\mathrm{cm})$ to sampling site $(10 \mathrm{Km})$. In contrast, moss $\mathrm{N}$ significantly differs in different spatial scales, which means that moss $\mathrm{N}$ was extremely sensitive to the environment in different spatial scales from patch size $(\mathrm{cm})$, microhabitats $(\mathrm{m})$, continuous dunes $(\mathrm{Km})$ to sampling site $(10 \mathrm{Km})$. Moss $\mathrm{P}$ and $\mathrm{K}$ were also spatial scale dependent in the current study. The changes in N, P and K were consistent with the 
conclusion that moss nutrients were plastic in different environment (Ball and Guevara, 2015). Because the change of moss stoichiometry is different, our results were partially consistent with our first hypothesis that moss stoichiometry varied with different spatial distance scales. The results of ANOVA analysis showed that the stoichiometry of moss was significant change with the changes of spatial distance scales, MAP and MAT. Moss N and P contents significantly increased with MAP, which might due to the founding that moss can assimilate nutrients from dry and wet deposition of air (Ball and Virginia, 2014; lii et al., 1987; Zhang and Wang, 2010). Moss can assimilate partly N and P nutrients from rainfall, snow and other sources. Wetness duration increased with MAP increased, which would benefit to the growth of moss. The growth of moss needs to accumulate large amounts of nitrogen and phosphorus. In addition, the increase of wetting is rich in microbial activity and accelerate nutrient turnover, which in turn promotes and accelerates biomass accumulation of moss in the Negev Desert (Kidron et al., 2010; Kidron, 2014). Moss P content was also influenced by MAT, thus the changes in moss $P$ content can contribute to moss growth in different temperature conditions. Thus, the climate factors (MAP, MAT) had a significantly affected the stoichiometry of moss. It is also support to the conclusion that mosses are very sensitive to environmental changes.

For soil under moss, soil OC was not influenced by moss in different spatial distance scales, which may due to the small changes in moss $C$ content. However, except for soil TK, soil TN and TP also did not differ among spatial scales. Our results suggested that soil OC, TN, TP and TK under moss soil were mainly influenced by moss patches in temperate desert (Li et al., 2019a). Pervious study founding that soil nutrients without moss were significantly influenced by different spatial distribution in the Gurbantunggut Desert (Tao et al., 2016). Thus, the moss can be considered as a stabilizer in desert surface, not only because they can fix sand (Weber et al., 2016), but also effectively provide stable soil nutrients. It is suggests that moss had a ecological function of stablling the soil nutrients. However, soil available nutrients varied significantly from different spatial scales in the Gurbantunggut Desert. The microbial processes, which are sensitive to environmental change in different sites, are related to the change of available nutrients.

\subsection{Differences in moss stoichiometry characteristic of above- and below-ground parts}

The statistical evidence showed moss stoichiometry in above-ground parts significantly differed to below-ground parts except for moss $\mathrm{N}$ content. The sacling exponents of moss $\mathrm{N}, \mathrm{P}$ and $\mathrm{K}$ content betwen above-ground and below-ground parts of moss were less than $1(0.251,0.389,0.442)$. In addtion, the sacling exponents of moss C:N, C:P, C:K, N:P, N:K, P:K rate were also less than 1 (Fig S3). The scaling exponent of nutrient showed the nutrient disproportionately distributed among plant organs with the different function type (Yan et al., 2016; Zhao et al., 2020). The nutrient contents of organs with similar function tend to change proportionally (the scaling exponent was 1), whereas the nutrient contents of organs with distinct function tend to change disproportionally (the scaling exponent was more or less than 1). The more active function of organ, the less its nutrient content is likely to change (Zhao et al., 2018). Our results were also consistent with the finding that plant stoichiometry was disproportionately

Page $11 / 32$ 
distributed in the above-ground and below-ground parts of plant (Zeng et al., 2017). These results supported our hypothesis that moss stoichiometry in above-ground parts of moss were significant higher than that in below-ground parts. The N:P in below-ground parts of moss was significantly higher than that in above-ground parts. Metabolic organs had higher $\mathrm{N}: \mathrm{P}$ ratio than structural organs, resulting from high $\mathrm{N}$ concentrations in metabolic organs (Zhang et al. 2018). Thus, it does not agree with the previous conclusion that moss have a vertical structure, which includes the above-ground "green" zone of alive, growing, and photosynthetically active parts, and the below-ground "brown" zone of senescent, dead, and decaying moss, rhizoids and other detritus (Lindo and Gonzalez, 2010). Moreover, the N vs. P scaling exponent in above-ground parts of moss was less than that in below-ground parts. The $\mathrm{N}$ vs. P scaling exponent under different nutrient availability can be reveal plant growth strategies.. The $\mathrm{N}$ vs. $\mathrm{P}$ exponents were less than 1 for plant, which implied a larger $\mathrm{P}$ investment of whole plants rather than $\mathrm{N}$ (Elser et al., 2010; Zhao et al., 2020). The N vs. $\mathrm{K}$ and $\mathrm{P}$ vs. $\mathrm{K}$ scaling exponent was significant linear in below-ground and above-ground parts of moss, respectively (Fig S1). There is a possible that the belowground parts of moss tended to be disproportionately assigned to more $\mathrm{N}$ and less $\mathrm{P}$ than the aboveground parts. It is a possible reason to explained the higher $\mathrm{N}$ vs. P scaling exponent of below-ground parts of moss than that of above-ground parts. Our result was consistent with global result that the scaling exponent of roots was higher than that of green leaves (Yuan et al., 2011). Recent global synthesis studies showed that the $\mathrm{N}$ vs. $\mathrm{P}$ scaling exponent of leaves and fine roots were $0.68(95 \% \mathrm{Cl}=$ 0.67-0.69) and 0.82 (95\% Cl=0.79-0.85), respectively (Tian et al., 2018; Wang et al., 2019), which also support our results that a higher $\mathrm{N}$ vs. $\mathrm{P}$ scaling exponent in below-ground parts than that in aboveground parts of moss. In vascular plants, fine root with hight $\mathrm{N}$ concentration can represent protein concentrations related to nutrient uptake (Collins et al., 2016). Leaves with hight $P$ and $K$ can reveal the hight potential of constructting biological compounds related to energy and growth (Collins et al., 2016). However, moss $\mathrm{N}$ content was insignificant difference between above-ground and below-ground parts, and $\mathrm{P}$ and $\mathrm{K}$ content in above-ground higher than that in below-ground parts. These results suggested that mosses need to invest more $\mathrm{P}$ and $\mathrm{K}$ to leaves for stable photosynthesis and improve environmental resistance, and more $\mathrm{N}$ to Rhizoids for effective and low-cost nutrient absorption (Withington et al., Caplan et al., 2014). Thus, our results were also consistent the results that the growth strategy of moss was driven by the above-ground parts of moss in a temperate desert (Li et al., 2019a), and that the basal parts of moss plants are a functionnal group of fine root, and include the stems and leaves buried by sand and soil fungi and bacteria (Birse et al., 1957; Jia et al., 2008). Our results provide strong evidence that the $\mathrm{N}$ vs. $\mathrm{P}$ scaling exponents varied among moss parts. Such a variation is a serious challenge for ecological models, which merely consider the $\mathrm{N}$ vs. P scaling exponent as an input parameter to predict plant growth and nutrient dynamics.

Except for C, significant correlations between moss stoichiometry in above-ground and below-ground parts were mostly observed. The results suggested that $\mathrm{C}$ assimilation differed from $\mathrm{N}, \mathrm{P}$ and $\mathrm{K}$ accumulation. Our results were also consistent with previous study that stoichiometry patterns in different plant organs had different distribution (He et al., 2015). In the current study, moss $\mathrm{C}$ positively correlated with moss $\mathrm{N}$ and $\mathrm{P}$, but negatively correlated with moss $\mathrm{K}$ in above-ground parts. Similar results 
were found in McGroddy et al, (2004). In contrast, Zheng and Shangguan (2007) reported negative correlations between leaf $\mathrm{C}$ and leaf $\mathrm{N}$, and between leaf $\mathrm{C}$ and $\mathrm{P}$ among Chinese Loess plateau flora. Thus, relationships of plant $\mathrm{C}, \mathrm{N}, \mathrm{P}$ and $\mathrm{K}$ were different among the life-form groups and the different ecosystems (Zhang et al., 2012; Zheng and Shangguan, 2007). The saturated model of SEM reported that moss $\mathrm{N}$ positively contributed to moss $\mathrm{C}$ accumulation, while moss $\mathrm{K}$ had a negative effect. The results indicated that there was a tradeoff in nutrient allocation between structural toughness and fast growth and that moss $\mathrm{C}, \mathrm{N}, \mathrm{P}$ and $\mathrm{K}$ were coordinated element. The strong correlation between leaf $\mathrm{N}$ and $\mathrm{P}$ is consistent with Gusewell, (2004), Mcgroddy et al, (2004), Wright et al, (2004; 2005a) and Han et al (2005). In this present study, moss $\mathrm{K}$ showed a weaker relationship with moss $\mathrm{N}$, and the scaling exponents of $\mathrm{N}$ vs. K, P vs. K were no significantly lined (Fig S1). These result was inconsistent with previous studies that plant K enhance plant $\mathrm{N}$ retention (Chiwa et al., 2019; Osaki, 1995). However, moss K significantly negative and positive correlated with moss $\mathrm{C}$ and $\mathrm{P}$, wihich indecate that the growth rate decreased and the environmental resistance increased were with $\mathrm{K}$ content increase. Thus, moss $\mathrm{C}, \mathrm{N}, \mathrm{P}$ and $\mathrm{K}$ elements need to be considered to be the core traits making up the moss growth and adaptation, and the C, N, P elements play a key role in these ecological process. The $\mathrm{K}$ was not limited for moss growth. The value of $\mathrm{N}: \mathrm{P}$ was less than 14 , and combining the ratio of $\mathrm{C}: \mathrm{N}, \mathrm{C}: \mathrm{P}$ and linear relationships of $\mathrm{C}, \mathrm{N}, \mathrm{P}$ elements, we suggested that moss growth was limited by $\mathrm{N}$ and $\mathrm{P}$ element.

\subsection{Relationships between moss and soil stoichiometry in temperature desert}

Scaling relationships between soil and moss nitrogen, phosphorus, potassium concentrations were no significant linear correlation (Fig S2). Moss have high stoichiometric homeostasis in the changing environment of soil nutrients. Previous studies found that vascular plant species with high homeostasis tend to be slower growing but also capable of maintaining growth when resources are limiting, given the potential for greater conservative use of resources, which was in line with our results (Zhao et al., 2021). However, moss N, P, K and soil available nutrients are positively correlated in most cases (Fig S4). Our results were support the conclusion that moss can assimilate and transport soil available nutrients by the below-ground parts (Ayres et al., 2006; Ball and Virginia, 2014; Raven, 2003). Most studies showed that moss can acquire nutrients directly from soil, stream, wet and dry atmosphere deposition (Ayres et al., 2006; Ball and Virginia, 2014). In this study, the results suggested that moss nutrients in above-ground parts mainly assimilate nutrients from below-ground parts of moss (Fig S5-7). Thus, soil nutrients and moss nutrients in below-ground parts also play crucial role to moss nutrients in above-ground parts uptake and individual growth.

Soil $\mathrm{NH}_{4}-\mathrm{N}$ and $\mathrm{NO}_{3}-\mathrm{N}$ significantly affected moss $\mathrm{N}$ content, and soil $\mathrm{NO}_{3}-\mathrm{N}$ was significantly correlated with moss $\mathrm{P}$. The results suggest that moss may use $\mathrm{NH}_{4}-\mathrm{N}$ as the main $\mathrm{N}$ source in $\mathrm{N}$-limited desert. This founding was similar to the conclusion with Takebayashi et al (2010). Ruan and Giordano (2017) considered that about $13 \%$ more energy is need to produce the same amount of biomass, if the $\mathrm{NO}_{3}-\mathrm{N}$ rather than $\mathrm{NH}_{4}-\mathrm{N}$ is used. Moreover, immobilization of $\mathrm{NH}_{4}-\mathrm{N}$ is reported to be faster than that of $\mathrm{NO}_{3}-\mathrm{N}$, while remineralization of immobilized $\mathrm{N}$ is slower in $\mathrm{NH}_{4}-\mathrm{N}$ than $\mathrm{NO}_{3}-\mathrm{N}$-treated soil (Ahmed et al., 1973; 
Azam and Malik., 1985; Herrmann et al., 2005; Zhou et al., 2020). This also explained that soil $\mathrm{NH}_{4}-\mathrm{N}$ significantly influenced by soil TN. It is possible that soil $\mathrm{NO}_{3}-\mathrm{N}$ was transported to moss for the balance between moss $\mathrm{P}$ and $\mathrm{K}$, between matter and energy, because moss is a rich phosphorus plant (Hao et al., 2005). Soil available nutrients significantly changed moss N, P and K contents in below-ground parts, which means that the rhizoid and stem in below-ground parts may not only have anchor function, but also have nutrients absorption and transmission functions.

In our study, the MAP, MAT, latitude, and longitude were significantly affected soil nutrients and moss $N$, $P$ and $\mathrm{K}$ elements in the Gurbantunggut Desert. MAP and longitude were significantly affected N, P and K elements in below-ground parts of moss, and soil nutrient was obviously influenced by MAT in three models (SEM). These results indicated that MAP and longitude directly affected moss stoichiometry, and the MAT indirectly affected moss $\mathrm{N}$ and $\mathrm{P}$ elements. Moss $\mathrm{N}$ and $\mathrm{P}$ elements were indirectly influenced by latitude. These results were consistent with previous studies that the variation of plant nutrient stoichiometry is influenced by many environmental factors (e.g. climate and soil properties). However, they were different to the conclusion that $\mathrm{N}$ and $\mathrm{P}$ concentrations decreased and N:P ratio increased with MAT and MAP (Reich and Oleksyn, 2004; Han et al., 2005 ). Hong et al. (2014) has reported that leaf P was negatively correlated with MAT and MAP, and root $P$ and N:P were negatively and positively correlated with MAT, respectively. He et al. (2015) found that MAT, MAP and the aridity index (AI) in the desert ecosystem had significant effects on leaf $P$, but no effects on stems and roots. In addition to climate factors, soil attributes are critical to plant growth and therefore affect plant nutrient stoichiometry. Research has found that leaf $\mathrm{N}$ and $\mathrm{P}$ concentrations are positively correlated with soil nutrients (Han et al., 2011, Luo et al., 2020). Our results suggessed that moss growth was directly influenced by MAP and longitude, and indirectly influenced by MAT, and the weakest effect of latitude in our study area. Thus, our results suggested that moss stoichiometry was influenced by climate factors and soil available nutrients.

\section{Conclusion}

The results of the present study show that moss growth limited by $\mathrm{N}$ and $\mathrm{P}$ element in temperature desert. Moss stoichiometry and soil available nutrients depended on spatial scales except moss $\mathrm{C}$ and soil OC. Moss nutrients in below-ground parts were mainly influenced by MAP, longitude and soil available nutrients. Above-ground and below-ground parts of moss had different functions. The moss rhizoid had some functions of vascular plant root, for example, anchor vegetal body, absorption and transmission of soil nutrients. The present findings contributed to an improved understanding of plant growth that moss have a strong capacity in environment adaptation by their roles in element balances.

\section{Declarations}

\section{Acknowledgements}

We would like to thank Yong-Xing Lu and Yi-Xiang Sun, for their assistance with sample collecting in field. This work was supported by National Natural Science Foundation of China $(42007099,41977099)$ and 
West Light Foundation of The Chinese Academy of Sciences (2018-XBQNXZ-B-016).

\section{References}

Aerts, R, Chapin, F.S, 2000. The mineral nutrition of wild plants revisited: A re-evaluation of processes and patterns. Adv Ecol Res 30: 1-67.

Ahmed, Z., Yahiro, Y., Kai, H., Harada, T., 1973. Transformation of the organic nitrogen becoming decomposable due to the drying of soil. Soil Science Plant Nutrition 19, 287-298.

Ayres E., van der Wal R., Sommerkorn M., Bardgett R.D., 2006. Direct uptake of soil nitrogen by mosses. Biology letters 2: 286-288. doi: 10.1098/rsbl.2006.0455.

Azam, F., Malik, K.A., 1985. Immobilization and remineralization of fertilizer $\mathrm{N}$ in soil supplemented with different organic materials. Pakistan Journal of Soil Science 1, 59-65.

Bai, X.J., Wang, B.R., An, S.S., Zeng, Q.C., Zhang, H.X., 2019. Response of forest species to C:N: P in the plant-litter-soil system and stoichiometric homeostasis of plant tissues during afforestation on the Loess Plateau. China. Catena 183: 104186. https://doi.org/10.1016/j.catena.2019.104186.

Bai, Y., Wu, J., Clark, C.M., Pan, Q., Zhang, L., Chen, S., Han, X., 2012. Grazing altersecosystem functioning and C:N: P stoichiometry of grasslands along a regional precipitation gradient. Journal Applied Ecology. 49: 1204-1215. doi.org/10.1111/j.1365-2664.2012.02205.x.

Ball, B.A., Guevara J.A., 2015. The nutrient plasticity of moss-dominated crust in the urbanized Sonoran Desert. Plant and Soil 389: 225-235. doi: 10.1007/s11104-014-2355-7.

Ball, B.A., Virginia R.A., 2014. The ecological role of moss in a polar desert: implications for abovegroundbelowground and terrestrial-aquatic linkages. Polar Biol 37: 651-664. doi: 10.1007/s00300-014-1465-2.

Bao, S., 2000. Soil and Agricultural Chemistry Analysis. 1st ed. . Beijing: China Agriculture Press.

Bardgett, R.D., Bowman, W.D., Kaufmann, R., Schmidt, S.K., 2005. A temporal approach to linking aboveground and belowground ecology. Trends in Ecology \& Evolution 20: 634-641. doi: 10.1016/j.tree.2005.08.005.

Bardgett, R.D., Wardle D.A., 2003. Herbivore-mediated linkages between aboveground and belowground communities. Ecology 84: 2258-2268. doi: Doi 10.1890/02-0274.

Barrett, J.E., Virginia, R.A., Lyons, W.B., McKnight, D.M., Priscu, J.C., Doran P.T., Fountain A.G., Wall D.H., Moorhead D.L., 2007. Biogeochemical stoichiometry of Antarctic Dry Valley ecosystems. J Geophys ResBiogeo 112. doi: Artn G01010 
Belnap, J., 2006. The potential roles of biological soil crusts in dryland hydrologic cycles. Hydrol Process 20: 3159-3178. doi: 10.1002/hyp.6325.

Birse, E.M., Landsberg, S. Y., H. G.C., 1957.. The effects of burial by sand on dune mosses. . Transactions of the British Bryological Society, 3: 285-301.

Bowker, M.A., Maestre, F.T., Eldridge, D., Belnap, J., Castillo-Monroy, A., Escolar, C., Soliveres, S., 2014. Biological soil crusts (biocrusts) as a model system in community, landscape and ecosystem ecology. Biodivers Conserv 23: 1619-1637. doi: 10.1007/s10531-014-0658-x.

Bowker, M.A., Maestre, F.T., Mau, R.L., 2013. Diversity and Patch-Size Distributions of Biological Soil Crusts Regulate Dryland Ecosystem Multifunctionality. Ecosystems 16: 923-933. doi: 10.1007/s10021013-9644-5.

Bowker, M.A., Mau, R.L., Maestre, F.T., Escolar, C., Castillo-Monroy, A.P., 2011. Functional profiles reveal unique ecological roles of various biological soil crust organisms. Funct Ecol 25: 787-795. doi: 10.1111/j.1365-2435.2011.01835.x.

Canton, Y., Roman, J.R., Chamizo, S., Rodriguez-Caballero, E., Moro, M.J., 2014. Dynamics of organic carbon losses by water erosion after biocrust removal. J Hydrol Hydromech 62: 258-268. doi: 10.2478/johh-2014-0033.

Caplan, J.S., Wheaton, C.N., Mozdzer, T.J., 2014. Belowground advantages in construction cost facilitate a cryptic plant invasion. AoB Plants, 6: 20. https://doi.org/10.1093/aobpla/plu020.

Chamizo, S., Rodriguez-Caballero, E., Roman, J.R., Canton, Y., 2017. Effects of biocrust on soil erosion and organic carbon losses under natural rainfall. Catena 148: 117-125. doi: 10.1016/j.catena.2016.06.017.

Chapin, F.S., 1980. The Mineral-Nutrition of Wild Plants. Annu Rev Ecol Syst 11: 233-260. doi: DOI 10.1146/annurev.es.11.110180.001313.

Chen, Y., Chen, L., Peng, Y., Ding, J., Li, F., Yang, G., 2016. Linking microbial C:N:P stoichiometry to microbial community and abiotic factors along a $3500 \mathrm{~km}$ grassland transect on the Tibetan plateau. Glob. Ecological Biogeography, 25, 1416-1427. doi.org/10.1111/geb.12500.

Chen, Y., Han, W., Tang, L., Tang, Z., Fang, J., 2013. Leaf nitrogen and phosphorus concentrations of woody plants differ in responses to climate, soil and plant growth form. Ecography, 36: 178-184. doi.org/10.1111/j.1600-0587.2011. 06833.x.

Chiwa, M., Sheppard, L.J., Leith, I.D., Leeson, S.R., Tang, Y.S., Cape, J.N., 2019. P and K additions enhance canopy $\mathrm{N}$ retention and accelerate the associated leaching. Biogeochemistry 142: 413-423. doi: 10.1007/s10533-019-00543-y. 
Collins, C.G., Wright, S.J., Wurzburger, N., 2016. Root and leaf traits reflect distinct resource acquisition strategies in tropical lianas and trees. Oecologia, 180(4): 1037-1047. https://doi.org/10.1007/s00442015-3410-7.

Couradeau, E., Karaoz, U., Lim, H.C., da Rocha, U.N., Northen, T., Brodie, E., Garcia-Pichel, F., 2016. Bacteria increase arid-land soil surface temperature through the production of sunscreens. Nat Commun 7. doi: ARTN 10373

Cuzzuol, G.R.F., Milanez, C.R.D., Gomes, J.M.L., Labate, C.A., Canal, E.C., 2013. Relationship between N, P, and $\mathrm{K}$ and the quality and stem structural characteristics of Caesalpinia echinata Lam. plants. TreesStruct Funct 27: 1477-1484. doi: 10.1007/s00468-013-0894-9.

Dai, A.G., 2013. Increasing drought under global warming in observations and models. Nat Clim Change 3: 171-171. doi: 10.1038/Nclimate1811.

Elbert, W., Weber B., Burrows, S., Steinkamp, J., Büdel, B., Andreae, M.O., Pöschl, U., 2012. Contribution of cryptogamic covers to the global cycles of carbon and nitrogen. Nature Geoscience 5: 459-462. doi: $10.1038 /$ ngeo1486.

Eldridge, D.J., Greene, R.S.B., 1994. Microbiotic Soil Crusts - a Review of Their Roles in Soil and Ecological Processes in the Rangelands of Australia. Aust J Soil Res 32: 389-415. doi: Doi 10.1071/Sr9940389.

Elser, J.J., 2000. Ecological stoichiometry: from sea lake to land. Trends in Ecology \& Evolution 15: 393394. doi: Doi 10.1016/S0169-5347(00)01956-X.

Elser, J.J., Acharya, K., Kyle, M., Cotner, J., Makino, W., Markow, T., Watts, T., Hobbie, S., Fagan, W., Schade, J., Hood, J. and Sterner, R.W. 2003. Growth rate-stoichiometry couplings in diverse biota. Ecology Letters, 6: 936-943. https://doi.org/10.1046/j.1461-0248.2003.00518.x

Elser, J.J., Bracken, M.E.S., Cleland, E.E., Gruner, D.S., Harpole, W.S., Hillebrand, H., Ngai, J.T., Seabloom, E.W., Shurin, J.B., Smith, J.E., 2007. Global analysis of nitrogen and phosphorus limitation of primary producers in freshwater, marine and terrestrial ecosystems. Ecol Lett 10: 1135-1142. doi: 10.1111/j.14610248.2007.01113.x.

Elser, J.J., Fagan, W.F., Kerkhoff, A.J., Swenson, N.G., Enquist, B.J., 2010. Biological stoichiometry of plant production: metabolism, scaling and ecological response to global change. New Phytol 186: 593-608. doi: 10.1111/j.1469-8137.2010.03214.x.

Falkowski, P., Scholes, R.J., Boyle, E., Canadell, J., Canfield, D., Elser, J., Gruber, N., Hibbard, K., Hogberg, P., Linder, S., Mackenzie, F.T., Moore, B., Pedersen, T., Rosenthal, Y., Seitzinger, S., Smetacek, V., Steffen, W., 2000. The global carbon cycle: A test of our knowledge of earth as a system. Science 290: 291-296. doi: DOI 10.1126/science.290.5490.291. 
Feng, S., Fu, Q., 2013. Expansion of global drylands under a warming climate. Atmos Chem Phys 13: 10081-10094. doi: 10.5194/acp-13-10081-2013.

Gao, B., Zhang, D., Li, X., Yang, H., Zhang, Y., Wood, A.J., 2015. De novo transcriptome characterization and gene expression profiling of the desiccation tolerant moss Bryum argenteum following rehydration. BMC genomics 16: 416. doi: 10.1186/s12864-015-1633-y.

Guo, Y., Yan, Z., Gheyret, G., Zhou, G., Xie, Z., Tang, Z. Wardle, D., 2020. The community-level scaling relationship between leaf nitrogen and phosphorus changes with plant growth, climate and nutrient limitation. Journal. Ecology. 108: 1276-1286. https://doi.org/10.1111/1365-2745.13369.

Gusewell, S., 2004. N : P ratios in terrestrial plants: variation and functional significance. New Phytol 164: 243-266. doi: 10.1111/j.1469-8137.2004.01192.x.

Gusewell, S., 2005. High nitrogen: phosphorus ratios reduce nutrient retention and second-year growth of wetland sedges. New Phytol 166: 537-550. doi: 10.1111/j.1469-8137.2005.01320.x.

Gusewell, S., Koerselman, M., 2002. Variation in nitrogen and phosphorus concentrations of wetland plants. Perspect Plant Ecol 5: 37-61. doi: Doi 10.1078/1433-8319-0000022.

Han, W.X., Fang, J.Y., Guo, D.L., Zhang, Y., 2005. Leaf nitrogen and phosphorus stoichiometry across 753 terrestrial plant species in China. New Phytol 168: 377-385. doi: 10.1111/j.1469-8137.2005.01530.x.

Han, W.X., Fang, J.Y., Reich, P., lan Woodward, F., Wang, Z.H., 2011. Biogeography and variability of eleven mineral elements in plant leaves across gradients of climate, soil and plant functional type in China. Ecol. Lett. 14: 788-796. https://doi.org/10.1111/j.1461-0248.2011.01641.x.

Hao, Z.Q., Ye, J., Jiang, P., Lin, F., 2005. Roles of bryophyte in nutrient cycling in dark coniferous forest of Changbai Mountains. Chinese Journal of Applied Ecology 16(12): 2263-2266 (in Chinese).

Harpole, W.S., Ngai, J.T., Cleland, E.E., Seabloom, E.W., Borer, E.T., Bracken, M.E.S., Elser, J.J., Gruner, D.S., Hillebrand, H., Shurin, J.B., Smith, J.E., 2011. Nutrient co-limitation of primary producer communities. Ecol Lett 14: 852-862. doi: 10.1111/j.1461-0248.2011.01651.x.

He, M., Zhang, K., Tan, H., Hu, R., Su, J., Wang, J., Huang, L., Zhang, Y., Li, X., 2015. Nutrient levels within leaves, stems, and roots of the xeric speciesReaumuria soongoricain relation to geographical, climatic, and soil conditions. Ecol Evol 5: 1494-1503. doi: 10.1002/ece3.1441.

He, M.Z., Zhang, K., Tan, H.J., Hu, R., Su, J.Q., Wang, J., Li, X.R., 2015. Nutrient levels within leaves, stems, and roots of the xeric species Reaumuria soongoricain relation to geographical, climatic, and soil conditions. Ecol. Evol. 5: 1494-1503. https://doi.org/10.1002/ece3.1441.

Hedin, L.O., 2004. Global organization of terrestrial plant-nutrient interactions. P Natl Acad Sci USA 101: 10849-10850. doi: DOI 10.1073/pnas.0404222101. 
Herrmann, A., Witter, E., Katterer, T., 2005. A method to assess whether 'preferential use' occurs after N-15 ammonium addition; implication for the N-15 isotope dilution technique. Soil Biol Biochem 37: 183-186. doi: 10.1016/j.soilbio.2004.06.008.

Hong, J., Wang, X., Wu, J., 2014. Stoichiometry of root and leaf nitrogen and phosphorus in a dry alpine steppe on the Northern Tibetan Plateau. PLoS ONE 9: 109052.

https://doi.org/10.1371/journal.pone.0109052.

Hu, R., Wang, X.P., Pan, Y.X., Zhang, Y.F., Zhang, H., 2014. The response mechanisms of soil N mineralization under biological soil crusts to temperature and moisture in temperate desert regions. Eur $\mathrm{J}$ Soil Biol 62: 66-73. doi: 10.1016/j.ejsobi.2014.02.008.

Huang, J.P., Yu, H.P., Guan, X.D., Wang, G.Y., Guo, R.X., 2016. Accelerated dryland expansion under climate change. Nat Clim Change 6: 166-+. doi: 10.1038/Nclimate2837.

lii, F.S.C, Oechel, W.C., Cleve, K.V., Lawrence, W., 1987. The role of mosses in the phosphorus cycling of an Alaskan black spruce forest. Oecologia 74: 310-315.

Implications. Plants, 10: 419. https://doi.org/10.3390/plants10020419

Ji, X.H., Zhang, Y.M., Tao, Y., Zhou, .X.B., Zhang, J., 2013. Size characteristic of moss crust pathes and its relationship to the evironmental factors in Gurbantunggut Desert. 33: 1803-1809.

Jia, R.L., Li, X.R., Liu, L.C., Gao, Y.H., Li, X.J., 2008. Responses of biological soil crusts to sand burial in a revegetated area of the Tengger Desert, Northern China. Soil Biol Biochem 40: 2827-2834. doi:

10.1016/j.soilbio.2008.07.029.

Kerkhoff, A.J., Enquist, B.J., Elser, J.J., Fagan, W.F., 2005. Plant allometry, stoichiometry and the temperature-dependence of primary productivity. Global Ecol Biogeogr 14: 585-598. doi: 10.1111/j.1466822X.2005.00187.x.

Kerkhoff, A.J., Fagan, W.F., Elser, J.J., Enquist, B.J., 2006. Phylogenetic and growth form variation in the scaling of nitrogen and phosphorus in the seed plants. Am Nat 168: E103-E122. doi: Doi $10.1086 / 507879$.

Kidron, G.J., Budel, B., 2014. Contrasting hydrological response of coastal and desert biocrusts. Hydrol Process 28: 361-371. doi: 10.1002/hyp.9587.

Kidron, G.J., Monger, H.C., Vonshak, A., Conrod, W., 2012. Contrasting effects of microbiotic crusts on runoff in desert surfaces. Geomorphology 139-140, 484-494

Kidron, G.J., Tal, S.Y., 2012. The effect of biocrusts on evaporation from sand dunes in the Negev Desert. Geoderma 179-180, 104-112. 
Kidron, G.J., Vonshak, A., 2012. The use of microbiotic crusts as biomarkers forponding, subsurface flow and soil moisture content and duration. Geoderma 181-182, 56-64.

Kidron, G.J., Vonshak, A., Dor, I., Barinova, S., Abeliovich, A., 2010. Properties and spatial distribution of microbiotic crusts in the Negev Desert. Catena 82: 92-101.

Knapen, A., Poesen, J., Galindo-Morales, P., De Baets, S., Pals, A., 2007. Effects of microbiotic crusts under cropland in temperate environments on soil erodibility during concentrated flow. Earth Surf. Process. Landf. 32, 1884-1901

Koerselman, W., Meuleman, A.F.M., 1996. The vegetation N:P ratio: A new tool to detect the nature of nutrient limitation. J Appl Ecol 33: 1441-1450. doi: Doi 10.2307/2404783.

Lambers, H., Mougel, C., Jaillard, B., Hinsinger, P., 2009. Plant-microbe-soil interactions in the rhizosphere: an evolutionary perspective. Plant and Soil 321: 83-115. doi: 10.1007/s11104-009-0042-x.

Li, Y.G., Zhou, X.B., Zhang, Y.M., 2019a. Moss patch size and microhabitats influence stoichiometry of moss crusts in a temperate desert, Central Asia. Plant and Soil. doi: 10.1007/s11104-019-04191-x.

Li, Y.G., Zhou, X.B., Zhang, Y.M., 2019b. Shrub modulates the stoichiometry of moss and soil in desert ecosystems, China. J Arid Land 11: 579-594. doi: 10.1007/s40333-019-0057-y.

Lindo, Z., Gonzalez, A., 2010. The Bryosphere: An Integral and Influential Component of the Earth's Biosphere. Ecosystems 13: 612-627. doi: 10.1007/s10021-010-9336-3.

Liu, J.G., Gou, X.H., Zhang, F., Bian, R., Yin, D.C. 2021. Spatial patterns in the C:N:P stoichiometry in Qinghai spruce and the soil across the Qilian Mountains, China. Catena, 196: 104814. https://doi.org/10.1016/j.catena.2020.104814

Liu, J.X., Fang, X., Tang, X.L., Wang, W.T., Zhou, G.Y., Xu, S., Huang, W.J., Wang, G.X., Yan, J.H., Ma, K.P., Du, S., Li, S.G., Han S.J., Ma Y.X. 2019. Patterns and controlling factors of plant nitrogen and phosphorus stoichiometry across China's forests. Biogeochemistry 143: 191-205. https://doi.org/10.1007/s10533019-00556-7

Liu, R., Zhao, H., Zhao, X., Drake, S., 2011. Facilitative effects of shrubs in shifting sand on soil macrofaunal community in Horqin Sand Land of Inner Mongolia, Northern China. Eur. J. Soil Biol 47: 316-321. https://doi.org/10.1016/j.ejsobi. 2011.07.006.

Luo, Y., Peng, Q.W.; Li, K.H.; Gong, Y.M.; Liu, Y.Y.; Han, W.X. 2021. Patterns of nitrogen and phosphorus stoichiometry among leaf, stem and root of desert plants and responses to climate and soil factors in Xinjiang, China. Catena, 199105100. https://doi.org/10.1016/j.catena.2020.105100.

Maestre, F.T., Castillo-Monroy, A.P., Bowker, M.A., Ochoa-Hueso, R., 2012. Species richness effects on ecosystem multifunctionality depend on evenness, composition and spatial pattern. J Ecol 100: 317-330. 
doi: 10.1111/j.1365-2745.2011.01918.x.

McGroddy, M.E., Daufresne, T., Hedin, L.O., 2004. Scaling of C : N : P stoichiometry in forests worldwide: Implications of terrestrial redfield-type ratios. Ecology 85: 2390-2401. doi: Doi 10.1890/03-0351.

Moody, E.K., Carson, E.W., Corman, J.R., Espinosa-Perez, H., Ramos, J., Sabo, J.L., Elser, J.J., 2018. Consumption explains intraspecific variation in nutrient recycling stoichiometry in a desert fish. Ecology 99: 1552-1561. doi: 10.1002/ecy.2372.

Oliver, M.J., Tuba, Z., Mishler, B.D., 2000a. The evolution of vegetative desiccation tolerance in land plants. Plant Ecol 151: 85-100. doi: Doi 10.1023/A:1026550808557.

Oliver, M.J., Velten, J., Wood, A.J., 2000b. Bryophytes as experimental models for the study of environmental stress tolerance: Tortula ruralis and desiccation-tolerance in mosses. Plant Ecol 151: 7384. doi: Doi 10.1023/A:1026598724487.

Osaki, M., 1995. Ontogenic Changes of N, P, K, Ca, and Mg Contents in Individual Leaves and Tubers of Potato Plants. Soil Sci Plant Nutr 41: 417-428. doi: Doi 10.1080/00380768.1995.10419604.

Pan, F.J., Zhang, W., Liu, S.J., Li, D.J., Wang, K.L., 2015. Leaf N:P stoichiometry across plant functional groups in the karst region of southwestern China. Trees-Struct Funct 29: 883-892. doi: 10.1007/s00468015-1170-y.

Pan, Z., Pitt, W.G., Zhang, Y., Wu, N., Tao, Y., Truscott, T.T., 2016. The upside-down water collection system of Syntrichia caninervis. Nat Plants 2: 16076. doi: 10.1038/nplants.2016.76

Pravalie, R., 2016. Drylands extent and environmental issues. A global approach. Earth-Sci Rev 161: 259278. doi: 10.1016/j.earscirev.2016.08.003.

Raven, J.A., 2003. Long-distance transport in non-vascular plants. Plant Cell Environ 26: 73-85. doi: DOI 10.1046/j.1365-3040.2003.00920.x.

Reich, P.B., Oleksyn, J., 2004. Global patterns of plant leaf $\mathrm{N}$ and $\mathrm{P}$ in relation to temperature and latitude. Proc. Natl. Acad. Sci. 101: 11001-11006. https://doi.org/10.1073/pnas.0403588101.

Reynolds, J.F., Stafford, Smith, D.M., Lambin, E.F., Turner, B.L., Mortimore, M., Batterbury, S.P.J., Downing, T.E., Dowlatabadi, H., Fernandez, R.J., Herrick, J.E., Huber-Sannwald, E., Jiang, H., Leemans, R., Lynam, T., Maestre, F.T., Ayarza, M., Walker, B., 2007. Global desertification: Building a science for dryland development. Science 316: 847-851. doi: 10.1126/science.1131634.

Rodriguez-Caballero, E., Knerr, T., Weber, B., 2015. Importance of biocrusts in dryland monitoring using spectral indices. Remote Sens Environ 170: 32-39. doi: 10.1016/j.rse.2015.08.034. 
Rong, Q.Q., Liu, J.T., Cai, Y.P., Lu, Z.H., Zhao, Z.Z., Yue, W.C., Xia, J.B., 2015. Leaf carbon, nitrogen and phosphorus stoichiometry of Tamarix chinensis Lour. in the Laizhou Bay coastal wetland, China. Ecol Eng 76: 57-65. doi: 10.1016/j.ecoleng.2014.03.002.

Ruan, Z.X., Giordano, M., 2017. The use of NH4+ rather than NO3- affects cell stoichiometry, C allocation, photosynthesis and growth in the cyanobacterium Synechococcus sp UTEX LB 2380, only when energy is limiting. Plant Cell Environ 40: 227-236. doi: 10.1111/pce.12858.

Rutherford, W.A., Painter, T.H., Ferrenberg, S., Belnap, J., Okin, G.S., Flagg, C., Reed, S.C., 2017. Albedo feedbacks to future climate via climate change impacts on dryland biocrusts. Sci Rep-Uk 7. doi: ARTN 44188

Sardans, J., Pe nuelas, J., 2015. Trees increase their P:N ratio with size: phosphorus; the treasure nutrient. Global Ecol. Biogeogr. 24: 147-156. https://doi.org/10.1111/geb.12231.

Sardans, J., Peñuelas, J., 2015. Potassium: A neglected nutrient in global change. Globle Ecololgy Biogeography. 24: 261-275.

Sardans, J., Peñuelas, J. 2021. Potassium Control of Plant Functions: Ecological and Agricultural Shi, L.J., Li, Q.K., Fu, X.L., Kou, L., Dai, X.Q., Wang, H.M., 2021. Foliar, root and rhizospheric soil C:N:P stoichiometries of overstory and understory species in subtropical plantations. Catena, 198: 105020. https://doi.org/10.1016/j.catena.2020.105020.

Srivastava, A.K., Shankar, A., Chandran, A.K.N., Sharma, M., Jung, K.H., Suprasanna, P., Pandey, G.K., 2020. Emerging concepts of potassium homeostasis in plants. Journal of Experimental Botany, 71: 608-619. https://doi.org/10.1093/jxb/erz458

Su, Y.G., Wu, L., Zhang, Y.M., 2012. Characteristics of carbon flux in two biologically crusted soils in the Gurbantunggut Desert, Northwestern China. Catena 96: 41-48. doi: 10.1016/j.catena.2012.04.003.

Su, Y.G., Wu, L., Zhou, Z.B., Liu, Y.B., Zhang, Y.M., 2013. Carbon flux in deserts depends on soil cover type: A case study in the Gurbantunggute desert, North China. Soil Biology and Biochemistry 58: 332-340. doi: 10.1016/j.soilbio.2012.12.006.

Takebayashi, Y., Koba, K., Sasaki, Y., Fang, Y.T., Yoh, M., 2010. The natural abundance of N-15 in plant and soil-available $\mathrm{N}$ indicates a shift of main plant $\mathrm{N}$ resources to $\mathrm{NO} 3$ - from $\mathrm{NH} 4+$ along the $\mathrm{N}$ leaching gradient. Rapid Commun Mass Sp 24: 1001-1008. doi: 10.1002/rcm.4469.

Tao, Y., Liu, Y.B., Wu, G.L., Zhang, Y., M., 2016. Regional-scale ecological stoichiometric charateristics and spatial disribution patterns of key elements in surface soil in the Junggar deseer, China. Acta Prataculturae Sinica 25: 13-23. 
Tao, Y., zhang, Y.M., 2012. Effects of leaf hair points on dew deposition and rainfall evaporation rates in moss crusts dominated by Syntrichia caninervis, Gurbantunggut Desert, northwestern China. . Acta Ecologica Sinica 32: 0007-0016.

Tian, D., Yan, Z.B., Niklas, K.J., Han, W.X., Kattge, J., Reich, P.B., Luo, Y.K., Chen, Y.H., Tang, Z.Y., Hu, H.F., Wright, I.J., Schmid, B., Fang, J.Y., 2018b. Global leaf nitrogen and phosphorus stoichiometry and their scaling exponent. Natl. Sci. Rev. 5: 728-739. https ://doi.org/10.1093/nsr/nwx142.

Tian, D., Yan, Z., Ma, S., Ding, Y., Luo, Y., Chen, Y., Du, E., Han, W., Kovacs, E.D., Shen, H., Hu, H., Kattge, J., Schmid, B., Fang, J. 2019. Family-level leaf nitrogen and phosphorus stoichiometry of global terrestrial plants. Sci. China Life Sci. 62: 1047-1057. https://doi.org/10.1007/s11427-019-9584-1.

Tränker, M., Tavakol, A., Jákli, B. 2018. Functioning of potassium and magnesium in photosynthesis, photosynthate translocation and photoprotection. Physiol. Plant. 163: 414-431.

van der Heijden, M.G.A., Bardgett, R.D., van Straalen, N.M., 2008. The unseen majority: soil microbes as drivers of plant diversity and productivity in terrestrial ecosystems. Ecol Lett 11: 296-310. doi:

10.1111/j.1461-0248.2007.01139.x.

Venterink, H.O., 2011. Does phosphorus limitation promote species-rich plant communities? Plant and Soil 345: 1-9. doi: 10.1007/s11104-011-0796-9.

Wang, M., Larmola, T., Murphy, M.T., Moore, T.R., Bubier, J.L., 2016. Stoichiometric response of shrubs and mosses to long-term nutrient ( $\mathrm{N}, \mathrm{P}$ and $\mathrm{K}$ ) addition in an ombrotrophic peatland. Plant and Soil 400: 403416. doi: 10.1007/s11104-015-2744-6.

Wang, Z., Yu, K., Lv, S., Niklas, K.J., Mipam, T.D., Crowther, T.W., Umana, M.N., Zhao, Q.i., Huang, H., Reich, P.B., Niu, S., 2019. The scaling of fine root nitrogen versus phosphorus in terrestrial plants: a global synthesis. Functional Ecology. 33: 2081-2094. https ://doi.org/10.1111/1365-2435.13434.

Wardle, D.A., Bardgett, R.D., Klironomos, J.N., Setala, H., van der Putten, W.H., Wall, D.H., 2004. Ecological linkages between aboveground and belowground biota. Science 304: 1629-1633. doi: 10.1126/science.1094875.

Wardle, D.A., Zackrisson, O., 2005. Effects of species and functional group loss on island ecosystem properties. Nature 435: 806-810. doi: 10.1038/nature03611.

Weber, B., Bowker, M., Zhang, Y., Belnap, J., 2016. Functional Roles of Biological Soil Crusts, Biological Soil Crusts: an Organizing Principle in Drylands. Springer, pp. 237-384.

Wright, I.J., Reich, P.B., Cornelissen, J.H.C., Falster, D.S., Garnier, E., Hikosaka, K., Lamont, B.B., Lee, W., Oleksyn, J., Osada, N., Poorter, H., Villar, R., Warton, D.I., Westoby, M., 2005. Assessing the generality of global leaf trait relationships. New Phytol 166: 485-496. doi: 10.1111/j.1469-8137.2005.01349.x. 
Wu, L., Zhang, Y.M., Zhang, J., Downing, A., 2015. Precipitation intensity is the primary driver of moss crust-derived $\mathrm{CO} 2$ exchange: Implications for soil $\mathrm{C}$ balance in a temperate desert of northwestern China. Eur J Soil Biol 67: 27-34. doi: 10.1016/j.ejsobi.2015.01.003.

Yan, Z., Li, P., Chen, Y., Han, W., Fang, J. 2016. Nutrient allocation strategies of woody plants: An approach from the scaling of nitrogen and phosphorus between twig stems and leaves. Scientific Reports, 6, 20099.

Yang, H.L., Zhang, D.Y., Li, H.Y., Dong, L.F., Lan, H.Y., 2015. Ectopic overexpression of the aldehyde dehydrogenase ALDH21 from Syntrichia caninervis in tobacco confers salt and drought stress tolerance. Plant Physiol Bioch 95: 83-91. doi: 10.1016/j.plaphy.2015.07.001.

Yang, Y., Liu, B.R., An, S.S., 2018. Ecological stoichiometry in leaves, roots, litters and soil among different plant communities in a desertified region of Northern China. Catena 166: 328-338. https://doi.org/10.1016/j.catena.2018.04.018.

Yu, Q., Wilcox, K., Pierre, K.L., Knapp, A.K., Han, X. and Smith, M.D. 2015. Stoichiometric homeostasis predicts plant species dominance, temporal stability, and responses to global change. Ecology, 96: 23282335. https://doi.org/10.1890/14-1897.1

Yuan, Z.Y., Chen, H.Y.H. 2009. Global trends in senesced-leaf nitrogen and phosphorus. Glob Ecol Biogeogr, 18: 532-542. https://doi.org/10.1111/j.1466-8238.2009.00474.x

Yuan, Z.Y., Chen, H.Y.H., Reich, P.B., 2011. Global-scale latitudinal patterns of plant fine-root nitrogen and phosphorus. Nat. Commun. 2: 234. https://doi.org/10.1038/ncomms1346.

Zeng, Q.C., Lal, Rattan, Chen, Y.N., An, S.S., 2017. Soil, leaf and root ecological stoichiometry of Caragana korshinskii on the Loess Plateau of China in relation to plantation age. PLoS One e0168890, 12. https://doi.org/10.1371/journal. pone.0168890.

Zeng, Q.C., Li, X., Dong, Y.H., An, S.S., Darboux, Fr'ed'eric, 2016. Soil and plant components ecological stoichiometry in four steppe communities in the loess plateau of china. Catena 147: 481-488. https://doi.org/10.1016/j. catena.2016.07.047.

Zhang F., Niu J., Zhang W., Chen X., Li C., Yuan L., Xie J. 2010. Potassium nutrition of crops under varied regimes of nitrogen supply. Plant and Soil, 335(1): 21-34.

Zhang, H., Yang, X., Wang, J., Wang, G.G., Yu, M., Wu, T., 2017. Leaf N and P stoichiometry in relation to leaf shape and plant size for Quercus acutissima provenances across China. Sci Rep 7: 46133. doi: 10.1038/srep46133.

Zhang, J., Zhang, Y.M., 2014. Diurnal variations of chlorophyll fluorescence and CO2 exchange of biological soil crusts in different successional stages in the Gurbantunggut Desert of northwestern China. Ecol Res 29: 289-298. doi: 10.1007/s11284-013-1122-1. 
Zhang, J.H., He, N.P., Liu, C.C., Xu, L., Chen, Z., Li, Y., Wang, R.M., Yu, G.R., Sun, W., Xiao, C.W., Chen, H.Y.H., Reich, P.B. 2020. Variation and evolution of C:N ratio among different organs enable plants to adapt to $\mathrm{N}$ limited environments. 26: 2534-2543. https://doi.org/10.1111/gcb.14973

Zhang, K., Su, Y.Z., Liu, T.N., Wang, T., 2016a. Leaf C:N:P stoichiometrical and morphological traits of Haloxylon ammodendron over plantation age sequences in an oasis-desert ecotone in North China. Ecol Res 31: 449-457. doi: 10.1007/s11284-016-1353-z.

Zhang, L.M., Wang, C.K., 2010. Carbon and nitrogen release during decomposition of coarse woody debris for eleven temperate tree species in the eastern mountain region of northeast China. Chinese Journal of Plant Ecology 34(4): 368-374 (in Chinese).

Zhang, Q., Xiong, G.M., Li, J.X., Lu, Z.J., Li, Y.L., Xu, W.T., Wang, Y., Zhao, C.M., Tang, Z.Y., Xie, Z.Q., 2018. Nitrogen and phosphorus concentrations and allocation strategies among shrub organs: the effects of plant growth forms and nitrogen-fixation types. Plant Soil, 427: 305-319. https://doi.org/10.1007/s11104018-36550.

Zhang, S.B., Zhang, J.L., Slik, J.W.F., Cao, K.F., 2012. Leaf element concentrations of terrestrial plants across China are influenced by taxonomy and the environment. Global Ecol Biogeogr 21: 809-818. doi: 10.1111/j.1466-8238.2011.00729.x.

Zhang, Y.G., Liu, X.J., Zhang, K.C., Zhang, D.Y., Guan, K.Y., 2018. An ABSCISIC ACID INSENSITIVE3-like gene from the desert moss Syntrichia caninervis confers abiotic stress tolerance and reduces ABA sensitivity. Plant Cell Tiss Org 133: 417-435. doi: 10.1007/s11240-018-1394-9.

Zhang, Y.M., Chen, J., Wang, L., Wang, X.Q., Gu, Z.H., 2007. The spatial distribution patterns of biological soil crusts in the Gurbantunggut Desert, Northern Xinjiang, China. J Arid Environ 68: 599-610. doi: 10.1016/j.jaridenv.2006.06.012.

Zhang, Y.M., Zhou, X.B., Yin, B.F., Downing, A., 2016b. Sensitivity of the xerophytic moss Syntrichia caninervis to prolonged simulated nitrogen deposition. Ann Bot-London 117: 1153-1161. doi: 10.1093/aob/mcw058.

Zhao S.C., He P., Qiu S.J., Jia L.L., Liu M.C., Jin J.Y., Johnston A.M. 2014. Long-term effects of potassium fertilization and straw return on soil potassium levels and crop yields in north-central China ScienceDirect. Field Crops Research, 169: 116-122.

Zhao, N., Liu, H., Wang, Q., Wang, R., Xu, Z., Jiao, C., He, N. 2018. Root elemental composition in Chinese forests: Implications for biogeochemical niche differentiation. Functional Ecology, 32: 40-49.

Zhao, N., Yu, G., Wang, Q., Wang, R., Zhang J., Liu C., He N.P. 2020. Conservative allocation strategy of multiple nutrients among major plant organs: From species to community. Journal of Ecology, 108: 267278. https://doi.org/10.1111/1365-2745.13256. 
Zhao, Y.G., Xu, M.X., 2013. Runoff and Soil Loss from Revegetated Grasslands in the Hilly Loess Plateau Region, China: Influence of Biocrust Patches and Plant Canopies. J Hydrol Eng 18: 387-393. doi: 10.1061/(Asce)He.1943-5584.0000633.

Zheng, S.X., Shangguan, Z., 2007. Spatial patterns of leaf nutrient traits of the plants in the Loess Plateau of China. Trees-Struct Funct 21: 357-370. doi: 10.1007/s00468-007-0129-z.

Zhou, X.B., Bowker, M.A., Tao, Y., Wu, L., Zhang, Y.M., 2018. Chronic nitrogen addition induces a cascade of plant community responses with both seasonal and progressive dynamics. Sci Total Environ 626: 99108. doi: 10.1016/j.scitotenv.2018.01.025.

Zhou, X.B., Tao, Y., Yin, B.F., Tucker, C., Zhang, Y.M. 2020. Nitrogen pools in soil covered by biological soil crusts of different successional stages in a temperate desert in Central Asia. Geoderma, 366(1):114166. https://doi.org/10.1016/j.geoderma.2019.114166

Zhou, X.B., Zhang, Y.M., Niklas, K.J., 2014. Sensitivity of growth and biomass allocation patterns to increasing nitrogen: a comparison between ephemerals and annuals in the Gurbantunggut Desert, northwestern China. Ann Bot-London 113: 501-511. doi: 10.1093/aob/mct275.

\section{Figures}

a

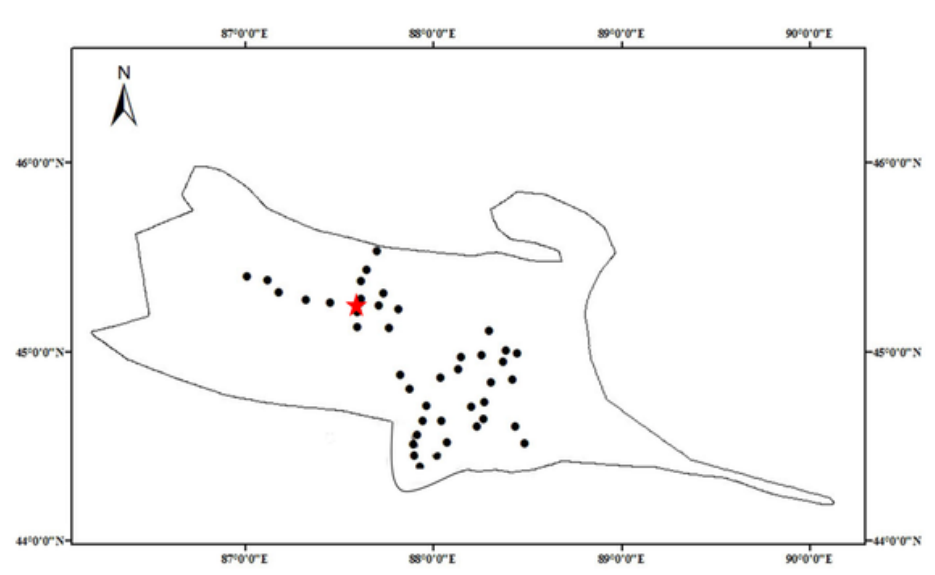

b

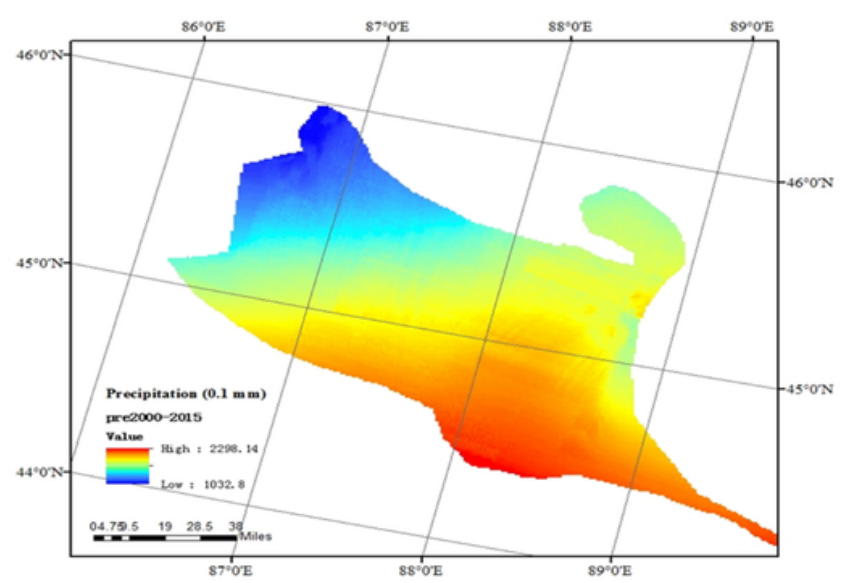

\section{Figure 1}

Locations where moss samples were identified and collected in the Gurbantunggut Desert (a); Annual mean precipitation was distributed in the Gurbantunggut Desert (b). The start indicates the continuous bottom of three typical sand dunes. Note: The designations employed and the presentation of the material on this map do not imply the expression of any opinion whatsoever on the part of Research Square concerning the legal status of any country, territory, city or area or of its authorities, or concerning the delimitation of its frontiers or boundaries. This map has been provided by the authors. 

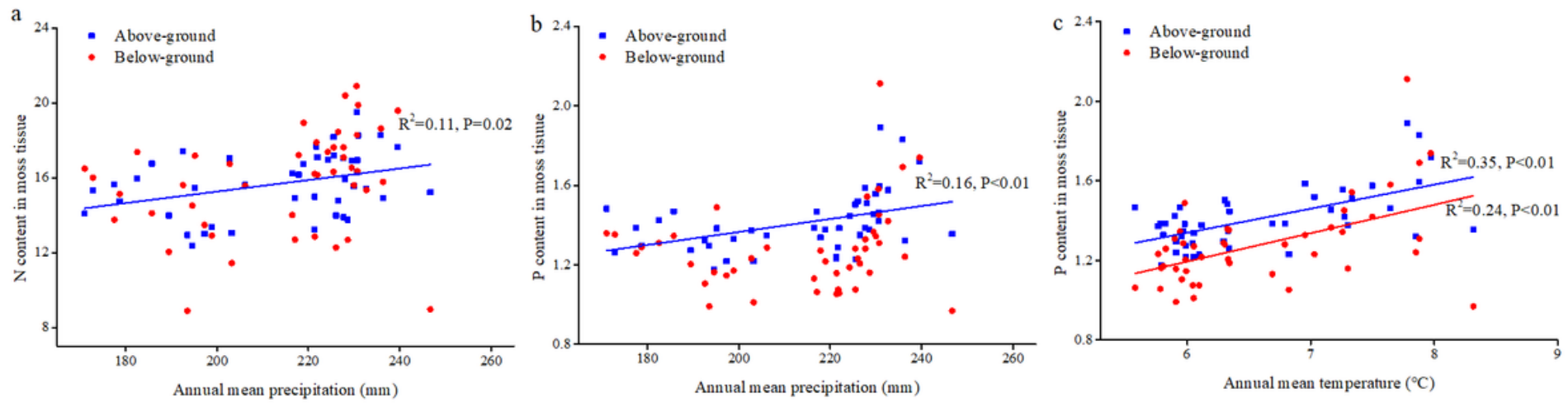

Figure 2

The changes in moss $\mathrm{N}$ and $\mathrm{P}$ contents with annual mean precipitation and annual mean temperature: $\mathrm{a}$, moss $\mathrm{N}$ content in different AMP; $\mathrm{b}$, moss $\mathrm{P}$ content in different AMP; $\mathrm{c}$, moss $\mathrm{P}$ content in different AMT.

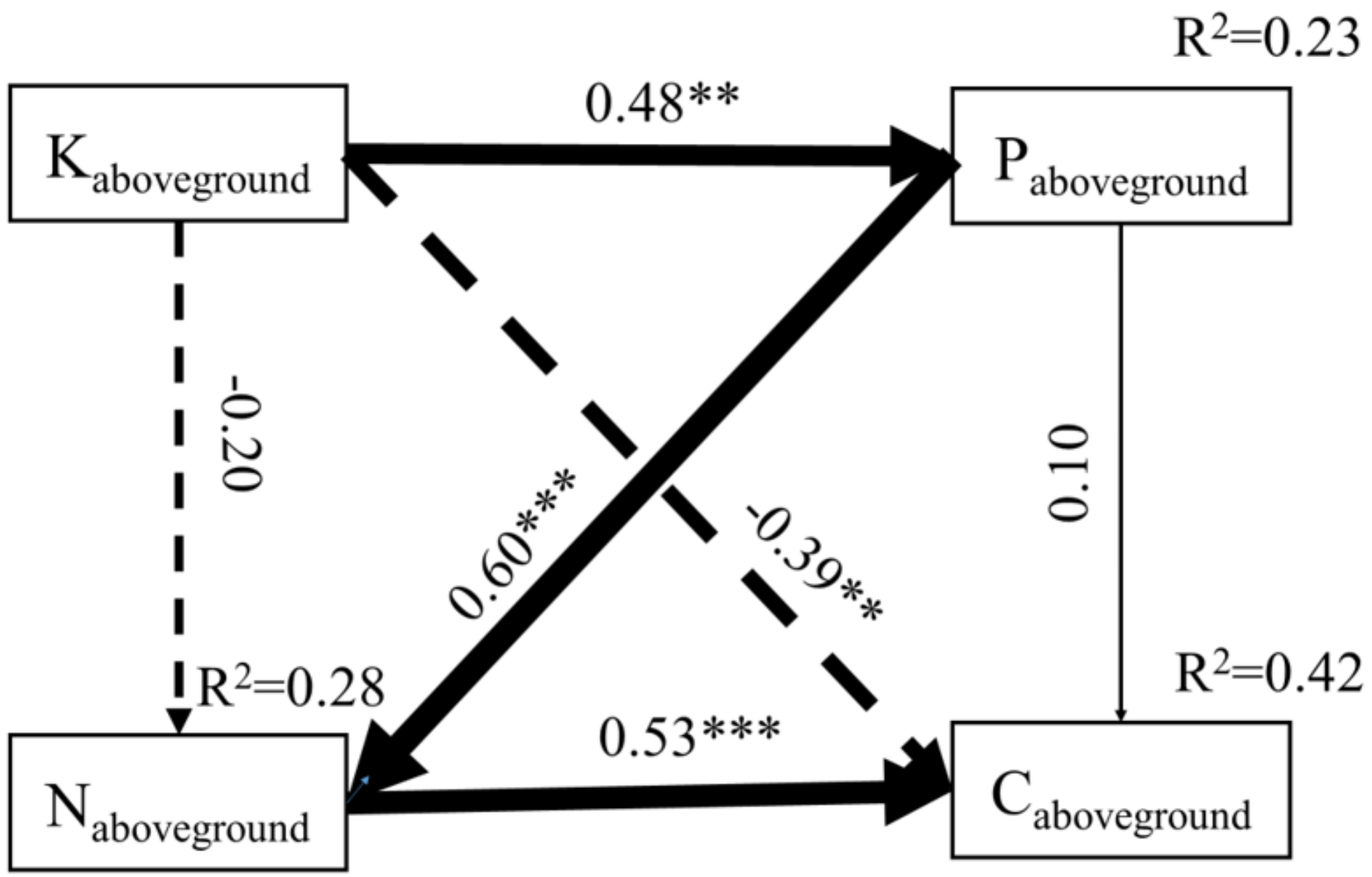

Figure 3

Relationships of C, N, P and K elements of above-ground parts of moss. Boxes represent measured variables. Standardized path coefficients are displayed, with the width of each arrow equivalent to the strength of the path. Solid lines represent the positive paths. Dashed lines indicate negative paths. The total amount of variance (R2) explained for each endogenous variable (that is, those with arrows pointing 
to them) is given on the top right of the variable. Corresponding probability values are included when $\mathrm{P}<0.20\left({ }^{*} \mathrm{P}<0.05, * * \mathrm{P}<0.01\right)$.

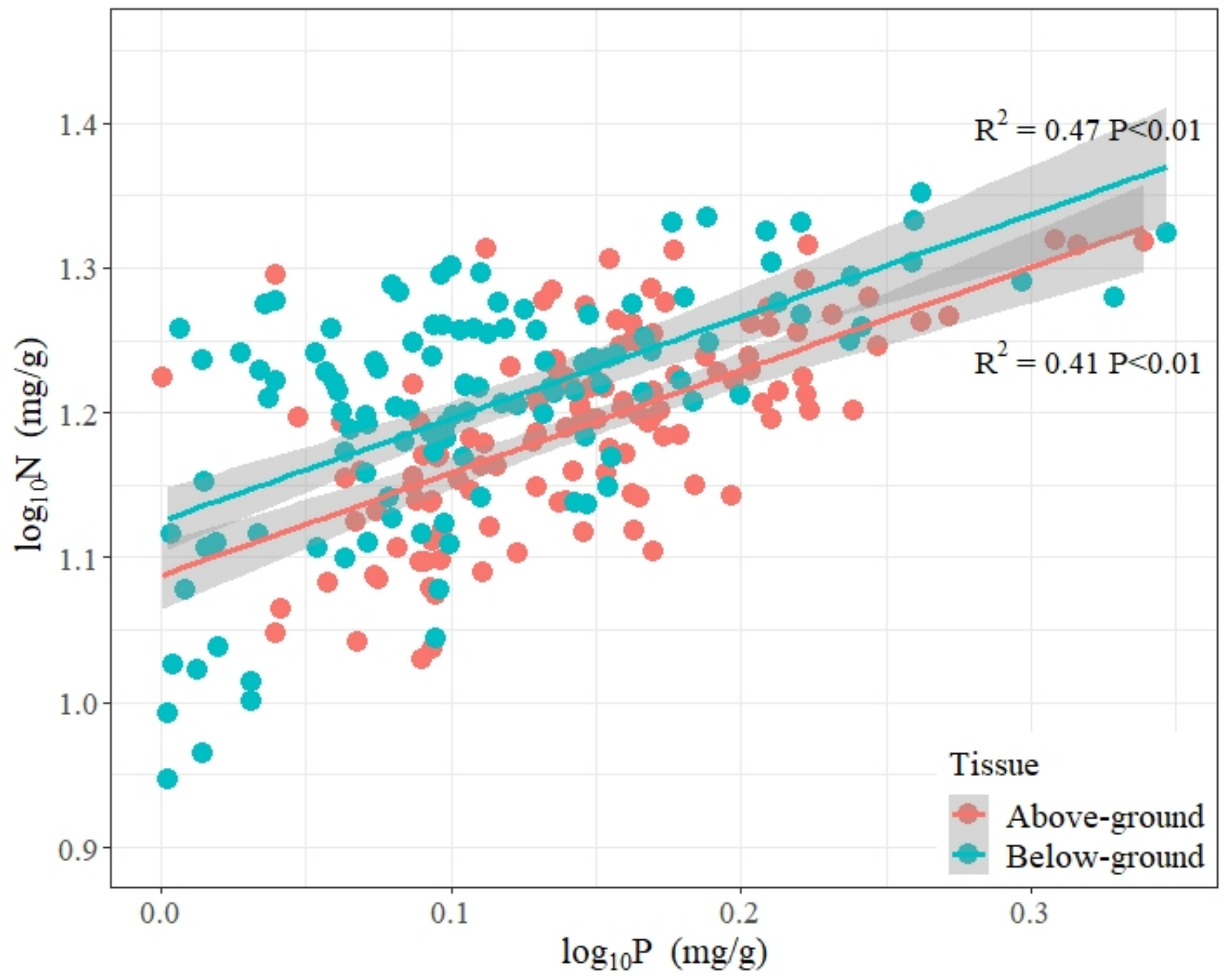

Figure 4

The N vs. P scaling exponents in above- and below-ground of moss.
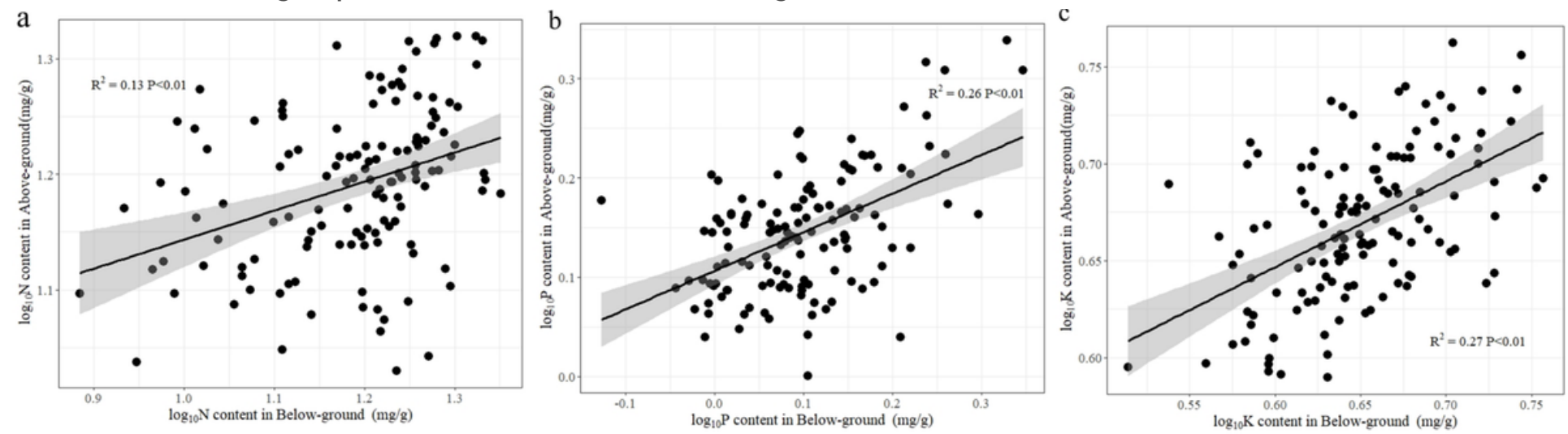

Figure 5 
Scaling relationships between above-ground and below-ground of moss nitrogen (or phosphorus, potassium) concentrations. (a) nitrogen element; (b) phosphorus element. (c) potassium element.
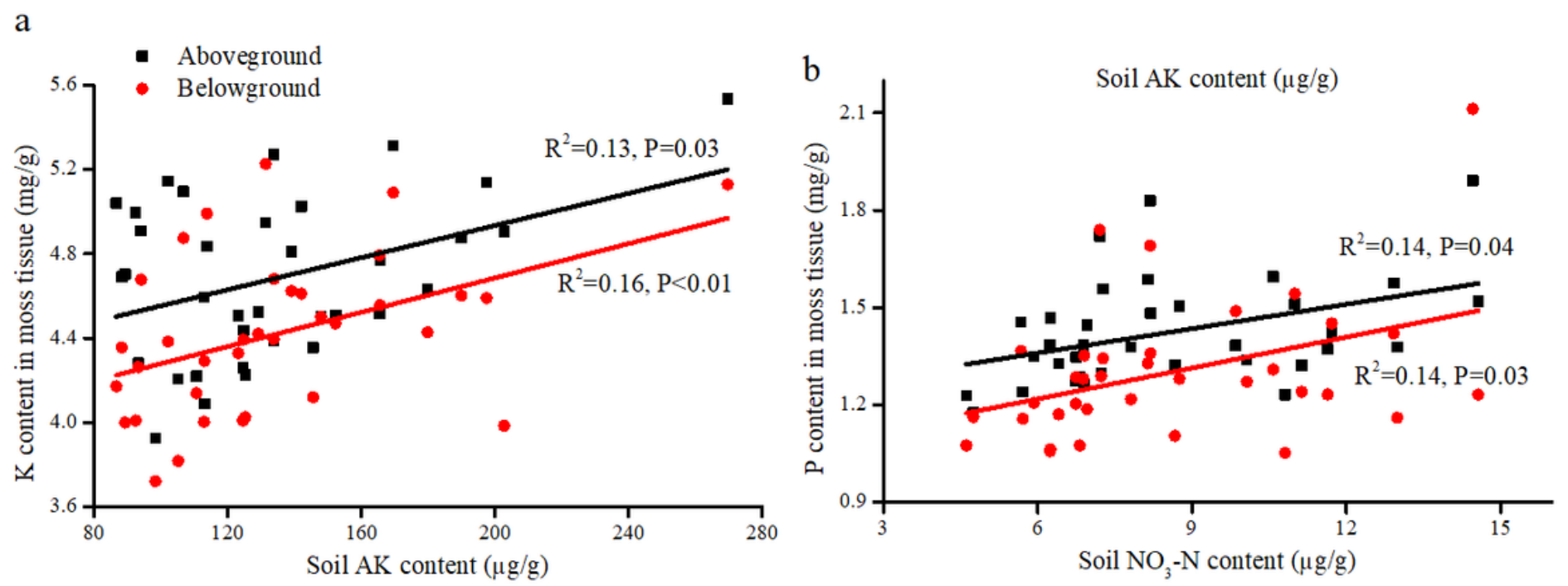

Figure 6

relationships between soil AK content and moss $\mathrm{K}$ contents (a), soil NO3-N content and moss P contents (b).

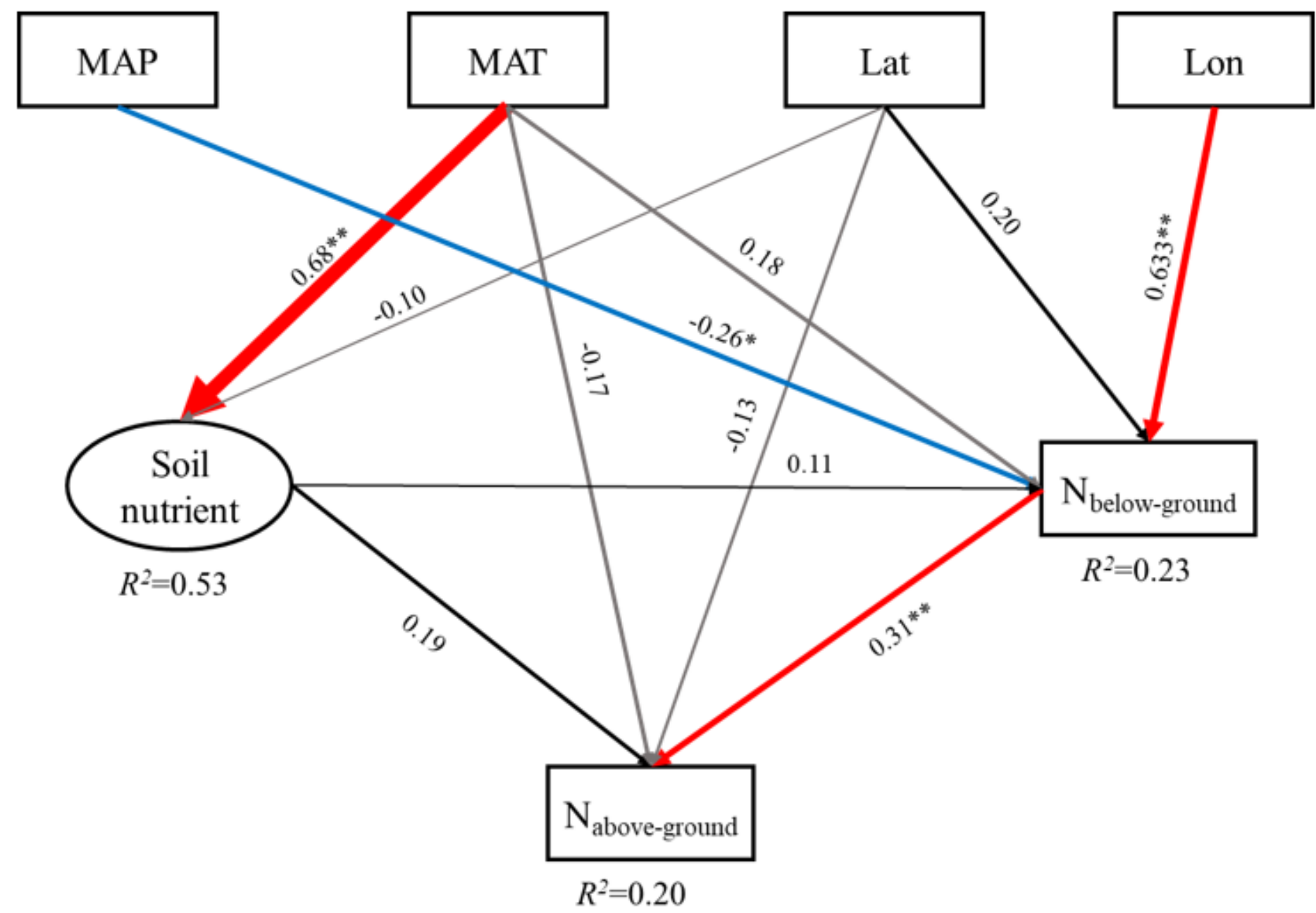




\section{Figure 7}

Final fitted structural equation models depicting relative effects of climate, geographical position, soil nutrient and moss $\mathrm{N}$ content in above-ground and below-ground parts. Boxes represent measured variables. Ellipse represent latent variable. Nabove-ground: nitrogen content in above-ground parts of moss; Nbelow-ground: nitrogen content in below-ground parts of moss. Standardized path coefficients are displayed, with the width of each arrow equivalent to the strength of the path. Red lines represent the positive paths $(P<0.05)$. Blue lines indicate negative paths $(P<0.05)$. The total amount of variance $(R 2)$ explained for each endogenous variable (that is, those with arrows pointing to them) is given on the below of the variable. Corresponding probability values are included when $P<0.50(* P<0.05$, $* \star P<0.01)$. The fit of the model was satisfactory (CFI=0.996, GFI $=0.971$, RMSEA $=0.023$, Chi-square $=11.760$, $\mathrm{P}=0.382$ ).

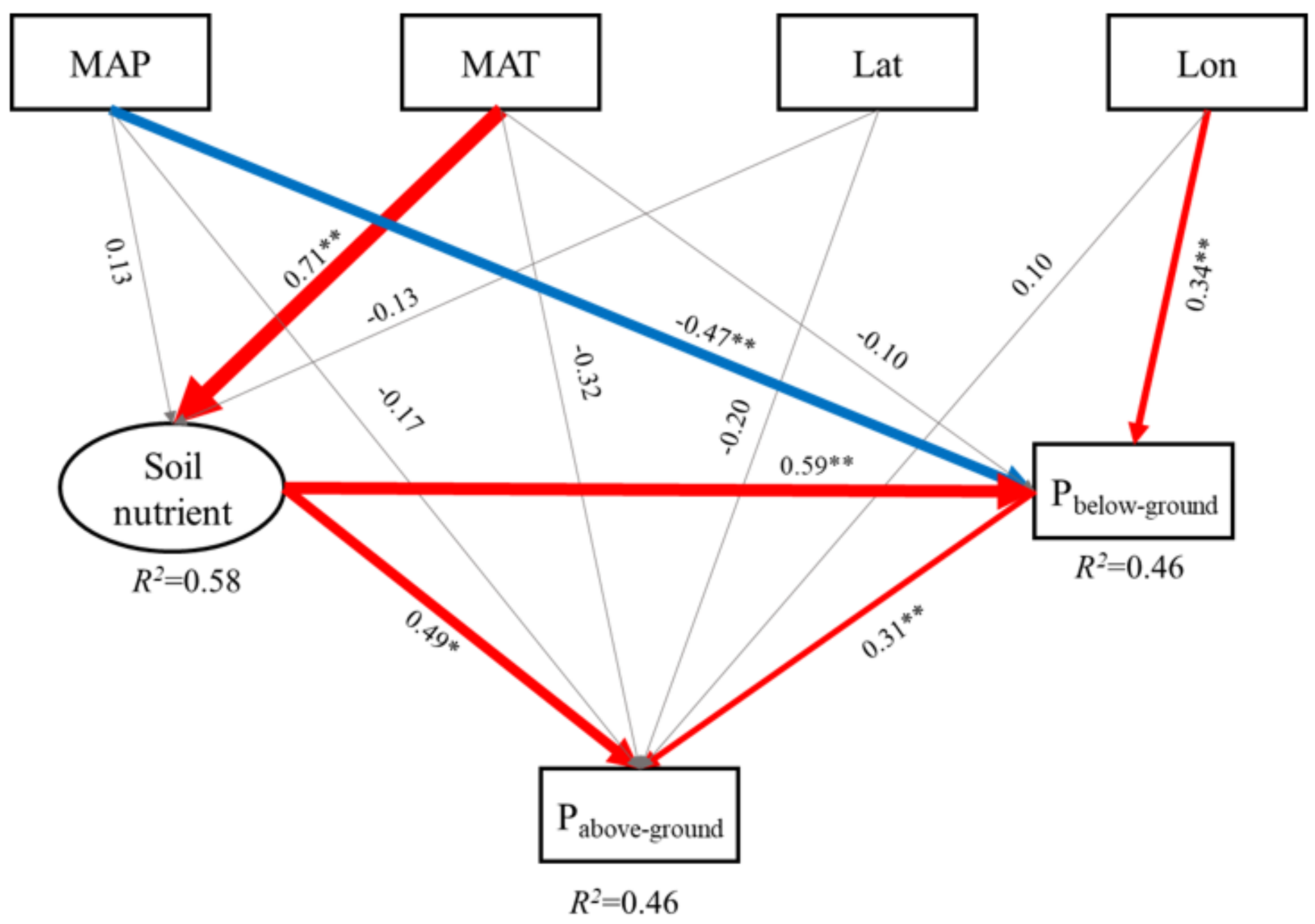

\section{Figure 8}

Final fitted structural equation models depicting relative effects of climate, geographical position, soil nutrient and moss $\mathrm{P}$ content in above-ground and below-ground parts. Boxes represent measured variables. Ellipse represent latent variable. Pabove-ground: phosphorus content in above-ground parts of moss; Pbelow-ground: phosphorus content in below-ground parts of moss. Standardized path 
coefficients are displayed, with the width of each arrow equivalent to the strength of the path. Red lines represent the positive paths. Blue lines indicate negative paths. The total amount of variance (R2) explained for each endogenous variable (that is, those with arrows pointing to them) is given on the top right of the variable. Corresponding probability values are included when $P<0.50(* P<0.05, * \star P<0.01)$. The fit of the model was satisfactory (CFI=0.970, GFI $=0.953$, RMSEA $=0.040$, Chi-square $=19.339$, $\mathrm{P}=0.055)$.

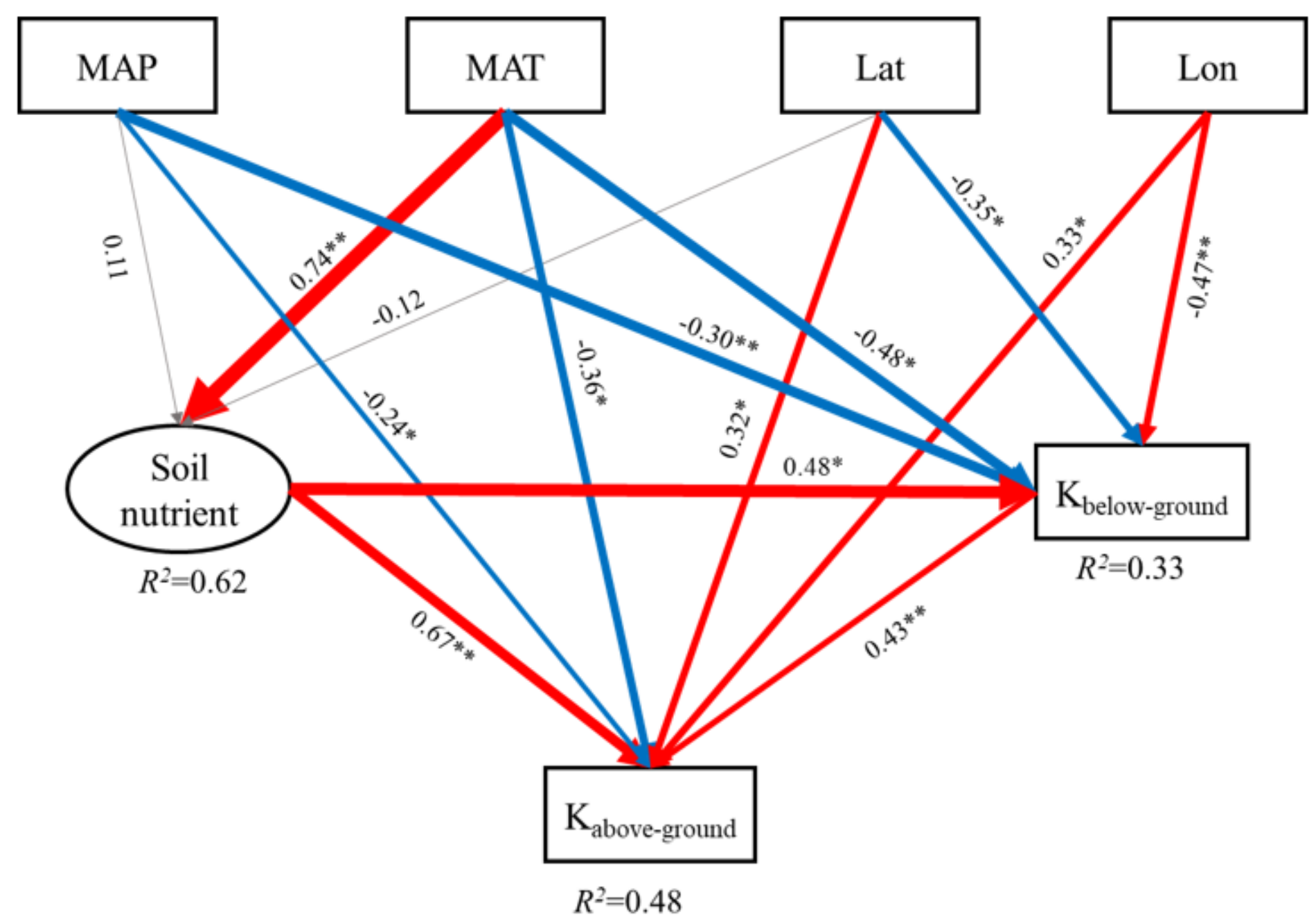

\section{Figure 9}

Final fitted structural equation models depicting relative effects of climate, geographical position, soil nutrient and moss $\mathrm{K}$ content in above-ground and below-ground parts. Boxes represent measured variables. Ellipse represent latent variable. Kabove-ground: potassium content in above-ground parts of moss; Kbelow-ground: potassium content in below-ground parts of moss. Standardized path coefficients are displayed, with the width of each arrow equivalent to the strength of the path. Solid lines represent the positive paths. Dashed lines indicate negative paths. The total amount of variance (R2) explained for each endogenous variable (that is, those with arrows pointing to them) is given on the top right of the variable. Corresponding probability values are included when $P<0.50$ ( $* P<0.05, * * P<0.01$ ). The fit of the model was satisfactory (CFI=0.979, $\mathrm{GFI}=0.959, \mathrm{RMSEA}=0.034$, Chi-square $=16.366, \mathrm{P}=0.128$ ). 


\section{Supplementary Files}

This is a list of supplementary files associated with this preprint. Click to download.

- suportinformation.docx 